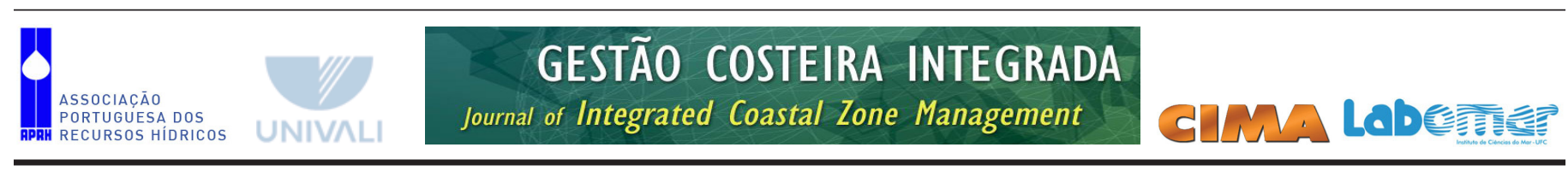

http://www.aprh.pt/rgci/pdf/rgci-475_Riddiford.pdf | DOI:10.5894/rgci475

\title{
The Albufera Initiative for Biodiversity: a cost effective model for integrating science and volunteer participation in coastal protected area management *
}

\author{
A Iniciativa Albufera para a Biodiversidade: um modelo exemplar em termos \\ de custo, eficiência e benefício para a integração da ciência com a participação \\ voluntária em processos de gestão de áreas protegidas costeiras **
}

\author{
Nick J. Riddiford ${ }^{\circledR, 1}$, Jeroen A. Veraart ${ }^{1,2}$, Inmaculada Férriz ${ }^{3}$, \\ Nick W. Owens ${ }^{1,4}$, Laura Royo ${ }^{3}$, Martin R. Honey ${ }^{1,5}$
}

-

\begin{abstract}
This paper puts forward a multi-disciplinary field project, set up in 1989 at the Parc Natural de s'Albufera in Mallorca, Balearic Islands, Spain, as an example of a cost effective model for integrating science and volunteer participation in a coastal protected area. Outcomes include the provision of a science base for the effective management of the site; training of Balearic and international biologists and protected area managers; and providing information materials for public awareness, education and general dissemination purposes. This has been achieved at low cost by using the voluntary sector. The project incorporates scientists, wetland managers, students, scholars and other citizens under the auspices of an international volunteer network (TAIB), working in partnership with the Parc management team. Long-term monitoring over a 25-year span of subjects as varied as insects, birds, land and aquatic ecosystems and communities has led to an improved ecological understanding of socio-economic as well as environmental impacts and threats for the catchment. This paper illustrates the added value of a long-term ecological knowledge base for decision making and capacity building in protected areas in order to reduce environmental impacts from socio-economic development in surrounding coastal zones. It describes how the science base has been used as a means of communication to encourage early action by policy makers to avoid negative outcomes of costly future impact on the public purse; and highlights how the economic value of long-term monitoring as an early warning system far outweighs the modest cost to society of an integrated participatory project based in the volunteer sector. The Albufera experience is offered as a cost effective model for other coastal and island sites.
\end{abstract}

Keywords: long-term studies, biodiversity, capacity building, environmental education, volunteers, economic values

@ - Corresponding author: nick.riddiford@taib.info,

1 - The Albufera Initiative for Biodiversity (TAIB), Schoolton, Fair Isle, Shetland ZE2 9JU, Scotland

2 - Alterra, Wageningen University and Research Centre, PO Box 47,6700 AA Wageningen, the Netherlands. E-mail: jeroen.veraart@wur.nl,

3 - Associació TAIB, c/Porto, 4.4rt A., E-07014, Palma, Mallorca, Balearic Islands, Spain.e-mails: Férriz - macu@taib.info; Royo-laura@taib.info

4-22 Springfield Close, Weybourne, Holt, Norfolk NR25 7TB, UK, e-mail: owensnw7@gmail.com

5 - Department of Life Sciences, Natural History Museum, Cromwell Road, London SW7 5BD, UK, e-mail: M.Honey@nhm.ac.uk

\footnotetext{
* Submission: 31 December 2013; Evaluation: 11 February 2014; Reception of revised manuscript: 15 May 2014; Accepted: 21 May 2014; Published on-line: 3 June 2014

** Translation to Portuguese (Title, Abstract, and Captions) by Artur Gil (on behalf of the Guest Editorial Board).
} 


\section{RESUMO}

Este artigo apresenta um projeto de campo multidisciplinar implementado em 1989 no Parque Natural de Albufera (Maiorca, Ilhas Baleares, Espanha) que pode ser considerado como um modelo exemplar em termos de custo, eficiência e benefício para a integração da ciência com a participação voluntária em processos de gestão de áreas protegidas costeiras. Os principais resultados deste projeto incluíram a produção de uma base cientifica para a gestão adequada do sítio; a formação de biólogos e gestores de áreas protegidas locais e internacionais; e a produção de materiais para educação, sensibilização e consciencialização ambiental da população local e grande público. Estes objetivos foram atingidos a baixo custo devido ao recurso ao voluntariado. Este projeto integrou cientistas, gestores de áreas protegidas, estudantes, bolseiros e outros cidadáos sob a égide de uma rede internacional de voluntariado (TAIB), que tem colaborado ativamente com a equipa de gestão do Parque Natural. A monitorização integrada a longo prazo durante um periodo de 25 anos em dominios cientificos como a entomologia, ornitologia, ecologia terrestre e ecologia aquática, permitiu melhorar substancialmente o nível de conhecimento ecológico associado à componente sócio-económica da área de estudo, assim como os seus impactes ambientais e as ameaças que dai decorrem para a bacia hidrográfica. Este artigo demonstra a importância de uma monitorização ecológica integrada a longo prazo para apoio à decisão e para a capacitação de recursos em áreas protegidas, de modo a reduzir os impactes ambientais decorrentes do desenvolvimento sócio-económico das áreas costeiras da zona. Este trabalho descreve também como a ciência foi usada como meio de comunicação e sensibilização para estimular os decisores a agir antecipadamente, de modo a evitar os altos custos ambientais e financeiros para o erário público decorrentes dos impactes ambientais e sócio-económicos das politicas adotadas. Finalmente, este estudo realça a excelente relação custo-eficiência-benefício associada à monitorização ecológica integrada a longo prazo assente num projeto participativo integrado baseado em voluntariado, constituindo também um sistema de alerta precoce eficiente, de baixo custo e com elevado benefício para a sociedade. A experiência de Albufera é assim proposta como um modelo válido apto para ser aplicado com sucesso noutros sitios costeiros e pequenas ilhas.

Palavras-chave: Estudos de longo prazo, biodiversidade, capacitação de recursos, educação ambiental, voluntariado, valoração económica.

\section{INTRODUCTION}

Effective conservation management has a cost. The act of declaring a protected area does not in itself guarantee safeguarding its environmental values. The perception that management "looks after itself" is seriously flawed. Planning, defining objectives, drawing up and implementation of management plans all require science, personnel... and money.

The objectives of this paper are:

- to demonstrate the added value and cost effectiveness of long-term ecological field studies as an essential element of effective integrated coastal zone management;

- to illustrate the hidden financial contribution these studies make in revealing issues and impacts, which if not remedied, can lead to severe future costs to society well beyond the protected area;

- to offer a field research model which may prove of interest or relevance to other coastal and island sites in the Mediterranean.

The model is a long-term field project entitled The Albufera Initiative for Biodiversity (TAIB). Launched in 1989, the project gives scientific support to the Parc Natural de s'Albufera on the island of Mallorca. The description outlines the structure of the initiative, the ways in which it feeds conservation knowledge into management of the Parc, and socio-economic implications of its findings. Most important of all, it puts forward a cost-effective model for maximizing results from limited financial outlay.

\section{BACKGROUND}

The concept for the project originated with Max Nicholson, doyen of World conservation, and was made possible by the support and intervention of Joan Mayol, then Director of the Parc Natural de s'Albufera.
Nicholson's vision was to create a multi-purpose approach to field conservation, incorporating scientists from different disciplines working alongside teams of volunteers in close partnership with the Parc Directorate and staff. This formula, often referred to nowadays as citizen science (Bäckstrand, 2004; van Vliet et al., 2013), was designed to have implications for coastal zone management, didactics (Costa et al., 2013) and capacity building (Echevarría et al., 2013).

\subsection{The Project}

\subsubsection{A brief history}

In order to give the project initial impetus, Max Nicholson persuaded a succession of high profile UK scientists to fill the role of Principal Investigator: Professor Palmer Newbould 1989-90, Dr Franklyn Perring 1991-92 and Terry Wells 1993-1995. Professor Newbould devised and led the first ever University Environmental Masters course (University College London 1970); Perring devised and organised the first ever environmental Atlas, The Botanical Atlas of the British Isles (Perring \& Walters, 1962); and Wells of Monks Wood Experimental Station, UK, was an acknowledged world expert on orchid demographics. Impetus in the first two years was also provided by students and teachers from the UCL Masters course. Administrator throughout was Nick Riddiford, ensuring a continuity which has lasted to this day.

Funding support came from the newly established Earthwatch Europe, an NGO originally developed in the United States to promote field research through the novel approach of finding volunteers willing to pay to participate alongside the scientists. Earthwatch Europe supported the project from 1989 to 1997, sending a stream of volunteers whose financial contribution ensured that the project had enough money to operate - though at low cost. 
Subsequently, although Earthwatch no longer acknowledged the project as one of its own, Earthwatch Europe did find the project some financial support through an African training programme, 1995-99, funded by the European Union and the UK Government's Darwin Initiative and a teacher training programme for European senior biology teachers financed through Glaxo Wellcome Education and ARCO Chemicals Teacher Fellowships.

Throughout this period, the Nicholson concept of scientists working alongside volunteers was maintained. In 25 years (1989-2013), the project has welcomed seventy scientists from 10 countries, representing a wide range of biological, geographical and conservation management disciplines. The majority of scientists were invited for specific tasks but a core of these committed their free time to the project on a more regular basis.

The change in funding status from 1997 meant that the project was no longer "Earthwatch Europe Project S'Albufera". In response, the well established team of scientists formed themselves into The Albufera International Biodiversity group (team TAIB for short), an appropriate term as the team drew from several European countries.

Tables 1 to 3 summarise the history and progress of Project S'Albufera.

\subsubsection{The current structure}

The current structure remains largely faithful to the format established in 1989. Two, three or four field sessions are held every year, each for a period of two weeks and usually in spring and autumn. Each team comprises 1012 participants. The participants, scientists and volunteers, receive no remuneration. In return, on-site accommodation and meals are provided free of charge - though the participants share the preparation of meals on a rota basis.

Table 1. Key moments in the development of TAIB's Project S'Albufera programme.

Tabela 1. Momentos-chave no desenvolvimento do Programa Albufera como projeto da TAIB.

1988 S'Albufera de Mallorca awarded conservation status by the Balearic government as a Parc Natural.

1988 Start of ornithological monitoring programme led by Parc management, reintroduction of 3 bird species, grazing management, hydrological rehabilitation measures (all led by Parc management).

1989 Project S'Albufera is launched by Earthwatch Europe after initial impetus of Max Nicholson.

1989 The Balearic government registers S'Albufera de Mallorca in the Convention on Wetlands of International Importance (with special reference to water birds), better known as the Ramsar Convention.

1993 The wetland area is seriously impacted by fires in 1992-1994, long-term research conducted of habitat requirements by reed bed birds such as Acrocephalus melanopogon based on initial studies done by Taylor (1993).

1994 onwards Parc Management starts monthly monitoring programme for water quality (temperature, salinity, oxygen, conductivity) in PN s'Albufera at 33 sites within the Parc.

1997 Direct Earthwatch funding ends.

1999 Parc Natural de s'Albufera opens Casa de las Universidades, including laboratory and dormitory, funded by the Balearic government.

2000 Balearic government becomes a co-funder of the ecological field work.

2003 The title The Albufera Initiative for Biodiversity is introduced as an alternative to Project S'Albufera.

2003 Baseline data for a wide range of plant and animal groups are published in a Biodiversity catalogue, extending knowledge of faunal and floral biodiversity.

2004 The monthly water quality monitoring programme is extended to nutrient measurements as the Balearic government implements the European Water Framework Directive.

2005 Research priorities formalised between Parc Directorate and TAIB.

2006 onwards TAIB extends the participatory process through consultation with local stakeholders (Traveset et al., 2006; Royo et al., 2010; Férriz, 2012, 2013).

2007 Associació TAIB formed as independent body to provide opportunities for local scientists. Development marks the growing commitment and skill base of Balearic field scientists, working in partnership with the international research community.

2013 As a result of the global financial crisis, Balearic government withdraws co-funding of TAIB project, severely reduces Parc budget and staff for ecological field studies.

2014: Balearic government and Parc renew financial support for training of local field ecologists and environmental managers. 
Table 2. Key developments in the nature conservation and ecological research programme.

Tabela 2. Desenvolvimentos-chave no programa de investigação em ecologia e conservaçấo da natureza.

1989 onwards Baseline inventory of geophysical features and better known environmental groups initiated alongside ecological field studies which in the early years included reed bed ecology, ornithological fieldwork, botanical studies and entomological fieldwork (Earthwatch Europe, 1991; Martinez \& Mayol, 1995). Long-term light trapping programme for Lepidoptera begins; and is still running, a significant example of the added value of long term ecological studies with new species discovered for Europe (e.g. Foster \& Riddiford, 2011), changes in Lepidoptera populations including invasive species moving north (Honey et al., 2007), alien pest species, relationships with climate variability (Abma, 2008; Associació TAIB, 2012; Férriz \& Herrero, 2012) and habitat structure (Honey et al., 2007).

1994 - 1996 Pilot study for Monitoring Mediterranean Wetlands (Riddiford \& Mayol, 1996; Tomàs-Vives, 1996).

1995 - 2008 An accord with Wageningen University sees a series of Masters studies through its Environmental Systems Analysis Group extend knowledge of the wetland's functions and values in partnership with the project and Parc.

1997 onwards Coastal dune studies added to programme, in conjunction with Mediterranean Institute for Advanced Studies (IMEDEA) and University of the Balearic Islands (Servera, 2009; Gelabert et al., 2002). Results show that biodiversity and dune development are strongly impacted by tourism development in both the coastline and Alcudia bay (Whittingham, 1999; Traveset $e t$ al., 2006; Royo et al., 2007, 2008; Férriz, 2009). Restoration recommendations are made.

1999 onwards Aquatic ecological fieldwork by TAIB (Veraart, 1999) is compared with similar pre-1989 data (Martinez, 1988) and monthly water quality time series collected by Parc staff. Outcome: a post-1988 decline in species diversity was mostly explained by increased salinity levels while high nutrient levels resulted in high abundancies of cosmopolitan aquatic species (see Veraart et al., 2004). Study repeated in spring 2000-2001, 2003-2005 and at two year intervals 2008-2012 enabling TAIB to assess longterm changes within the structure and development of the aquatic vegetation in relation to water quality and inter-annual climate variability.

2002 - 2008 Studies by Sato (2002), Sato \& Riddiford (2008), Sargeant (2002) and Salazar et al. (2006) use dragonflies and Ardeidae respectively to increase knowledge of the relationship between species diversity, niche partitioning, habitat requirements and management measures within s'Albufera de Mallorca.

2009 Various studies launched by Associació TAIB relating to socio-economic values of environmental conservation and planning both within (e.g. Férriz, 2010; Royo et al., 2010) and outside the Parc boundaries (e.g. Royo et al., 2010; Férriz, 2012, 2013).

2011 Gabinet d'Analisi Ambiental $i$ Territorial (2011) combines research results for water quality, aquatic ecology \& hydrology from TAIB fieldwork \& University of Barcelona (Suarez \& Pretus, 2008). TAIB data demonstrate further aquatic biodiversity decline since 1999; after 2000, additional loss in species diversity mainly explained by eutrophication. Long-term salinity and conductivity time series collected by Parc staff show the trend of increased salinity levels has halted at the southern edge of the wetland area since 2000 while the levels continue to increase near the coastal zone (Riddiford \& Férriz, 2009).

Table 3. Key moments in the capacity building programme.

Tabela 3. Momentos-chave no programa de capacitação de recursos

1989 Parc Directorate and Earthwatch Europe sign protocol to incorporate local graduates in the fieldwork programme.

1995 - 1997 Programme of training for senior biology teachers from France, Netherlands and UK, funded by Glaxo plc.

1995 - 1999 African training programme launched, coordinated by TAIB, funded by European Union and UK Darwin Initiative.

2003 - 2007 Capacity building programme for Mediterranean wetland managers in conjunction with MedWet Coast.

2005 TAIB's first website is launched: www.taib-initiative.org.

2005 onwards Capacity building extended to staff of protected areas and environmental NGOs in conjunction with WWF Mediterranean and other international bodies.

2012 Protected Area Species and Habitats Coordinator for Guinea Bissau brings the participant country count to 50 .

2013 Associació TAIB launches the new website: www.taib.info.

2014 New source of Balearic government funding targets training of local field ecologists and environmental managers. 
The teams have a capacity building as well as a field research element so the ratio of scientists to volunteers is high, often approaching $1: 1$. Seven members of the scientific team have attended regularly for more than 10 years, and at least three are present with each team. This ensures continuity of the research and training programmes. Other scientific expertise is sought in relation to newly opened lines of study, thus adding fresh blood to the team on an annual basis.

\subsubsection{Volunteers}

In the Earthwatch years, the majority of volunteers were members or retired members of the professions, e.g. teachers, medics, administrators, etc. Earthwatch Europe also secured grants to sponsor other members of society, and from other European countries. To add to the international mix, two free places were reserved for local, Balearic, volunteers under an agreement with the Balearic Government's Conselleria d'Agricultura i Pesca (later the Conselleria de Medi Ambient). These were mainly graduate and post-graduate science students from the University of the Balearic Islands. Their participation allowed TAIB to develop its capacity building programme and this was further enhanced by the African programme which gave protected area managers from seven sub-Saharan countries, and others working in conservation and allied activities, the opportunity to experience at first hand the management and monitoring activities at the Parc.

\subsubsection{The capacity building programme}

As the project became better known, regionally and internationally, the number of volunteers from the Balearic Islands and mainland Spain grew. The Conselleria de Medi Ambient intervened with funding support from 2000 and this was crucial because it allowed TAIB to use some of its funding to host conservation workers from countries around the Mediterranean and beyond. International awareness of the capacity building opportunities encouraged organisations such as WWF Mediterranean, MedWetCoast and the UNDP/GEF regional unit for Arab States to send protected area managers and conservation workers for TAIB's capacity building experience.

The capacity building courses incorporated into TAIB fieldwork periods are designed to be entirely practical and with flexibility to structure each course to the particular needs of the participants. The main aims of the courses are to: provide participants with practical experience of monitoring techniques, species identification and data collection; undertake capacity building in wetland management and protected area management generally; and permit participants to study and experience all aspects of nature reserve management alongside TAIB scientists and the Parc management team.

Over 450 volunteer trainees from 50 countries and all parts of the world have participated over the 25 years. A high proportion of oversees trainees have been protected area managers and conservation workers from developing countries. They took away with them practical knowledge of management planning, applying the MedWet monitoring protocol (Tomàs-Vives, 1996) to their own monitoring programme and much more. Many have stayed in contact with the project or its scientists and have benefited from further assistance and advice through email.

\subsubsection{The cost}

The annual cost of running a programme of this kind normally requires some $€ 15,000$ to $€ 20,000$. This may sound expensive but it covers day to day expenses, including administration, food and equipment, for up to 50 days in the field; and there is considerable added value when one takes into account that several of the scientists who volunteer their time and expertise free of charge would normally be contracted in their professional lives at $€ 500$ per day or more. Thus, an outlay of $€ 20,000$ brings in more than 10 times that value over the course of a year.

\subsection{The Site}

S'Albufera de Mallorca is the largest wetland in the Balearic Islands and is separated from the sea by a belt of coastal dunes (Fig. 1). A total of 1688 ha, incorporating approximately 1450 ha of wetland and over 200 ha of dune, received designation as a Parc Natural by the Balearic Government in 1988.

The wetland zone comprises a complex network of canals - products of a failed attempt to drain the site in the 1860s (Picornell \& Ginard, 1995) - extensive reed beds and shallow, open lagoons. The wetland is largely freshwater but with anomalies including extensive saltmarsh and saline lagoons in the north-east and a small set of abandoned salt pans in the south-east. An incomplete set of fossil dunes, remnants of an ancient coastline formed during the Riss glacial some 100,000 years before present, runs through the wetland parallel to the coast (Barceló \& Mayol, 1980; Servera, 2004). This, along with an intact band of coastal dunes, Es Comú (Fig. 1), and a strip of dune woodland on the southern border, add diversity to the Parc. The entire area is flat and at or just above sea level. The Parc's eastern boundary abuts Alcudia Bay, whose coastal strip has been heavily developed for tourism (Fig. 2).

Bordering the Parc's inland perimeter is an extensive zone largely given over to agriculture, much of it intensive (Fig. 3). Immediately beyond the perimeter are hundreds of small properties called Veles, many of them abandoned or with low levels of activity (Férriz, 2013). Though not in the Parc, the closest are incorporated within the Natura 2000 site. They act as a buffer zone between the Parc and the intensive agriculture which has developed over the last 50 years or so in the large plateau beyond which extends to the nearest towns of Sa Pobla and Muro (Royo et al., 2010; Férriz, 2013).

A series of settlements lie within the catchment area. The resident population has increased by nearly $50 \%$ in that area over the last 17 years (Table 4), as has the number of tourists which during the summer season outnumber residents tenfold (Andrew, 2011; Hof \& Blázquez-Salom, 2013; Figure 4). This puts enormous pressure on water resources and facilities, not least at pre-tourism sewage works inadequate for processing current volumes of wastewater. 


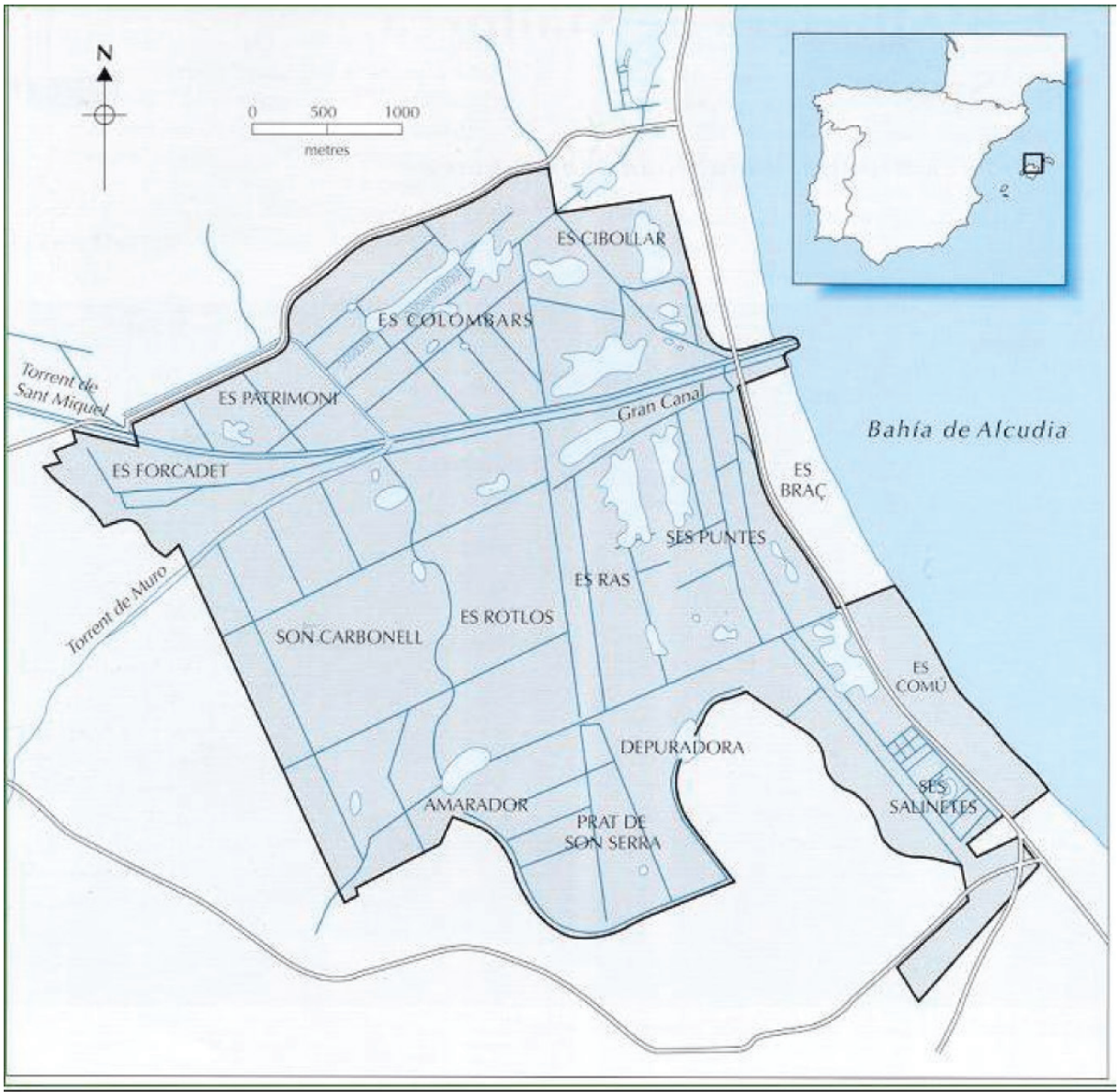

Figure 1. Map of the Parc Natural de s'Albufera, Mallorca and its regional context.

Figura 1. Enquadramento regional e localizaçāo do Parque Natural de Albufera em Maiorca.

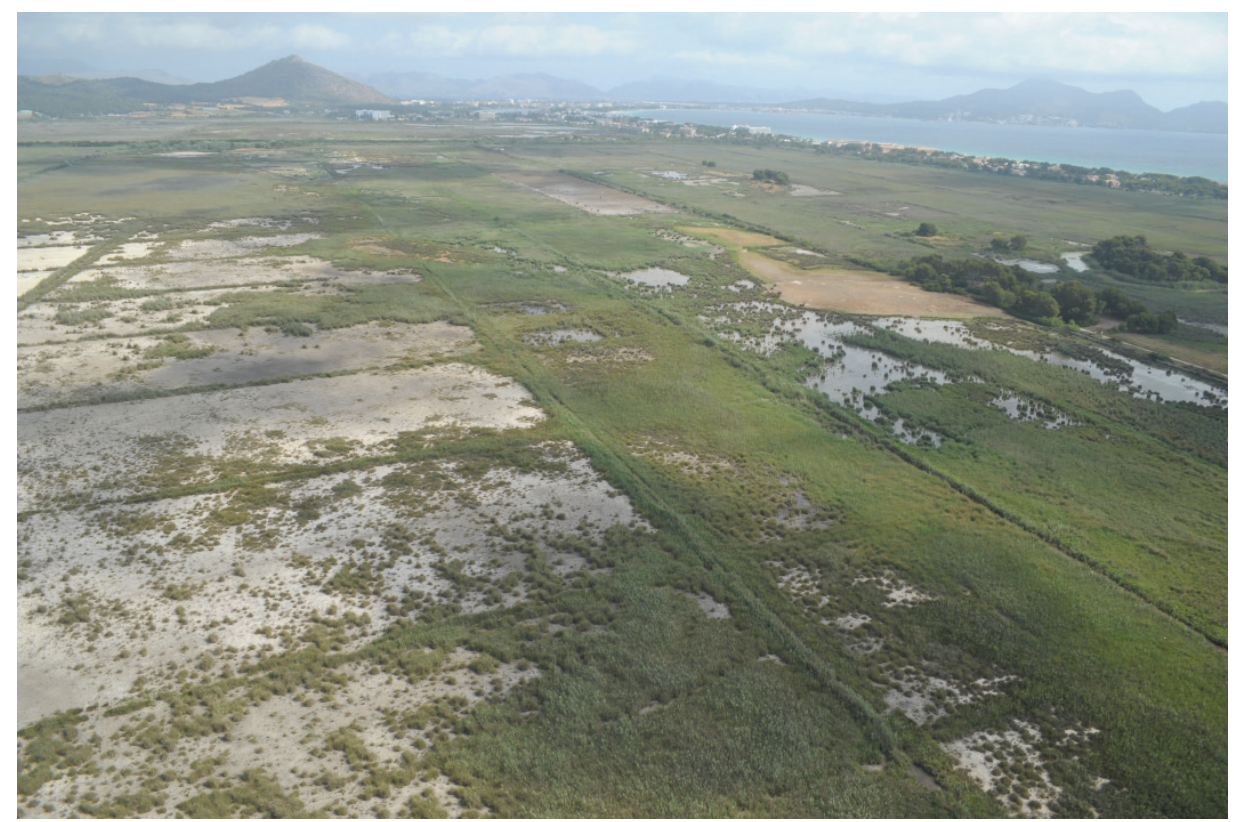

Figure 2. The Parc Natural de s'Albufera, Mallorca, showing extensive tourist urbanisation on its north-eastern border.

Figura 2. Ilustração da excessiva concentração urbanistica de cariz turístico na fronteira nordeste do Parque Natural de Albufera.

Photo: courtesy of P.N. s'Albufera de Mallorca 


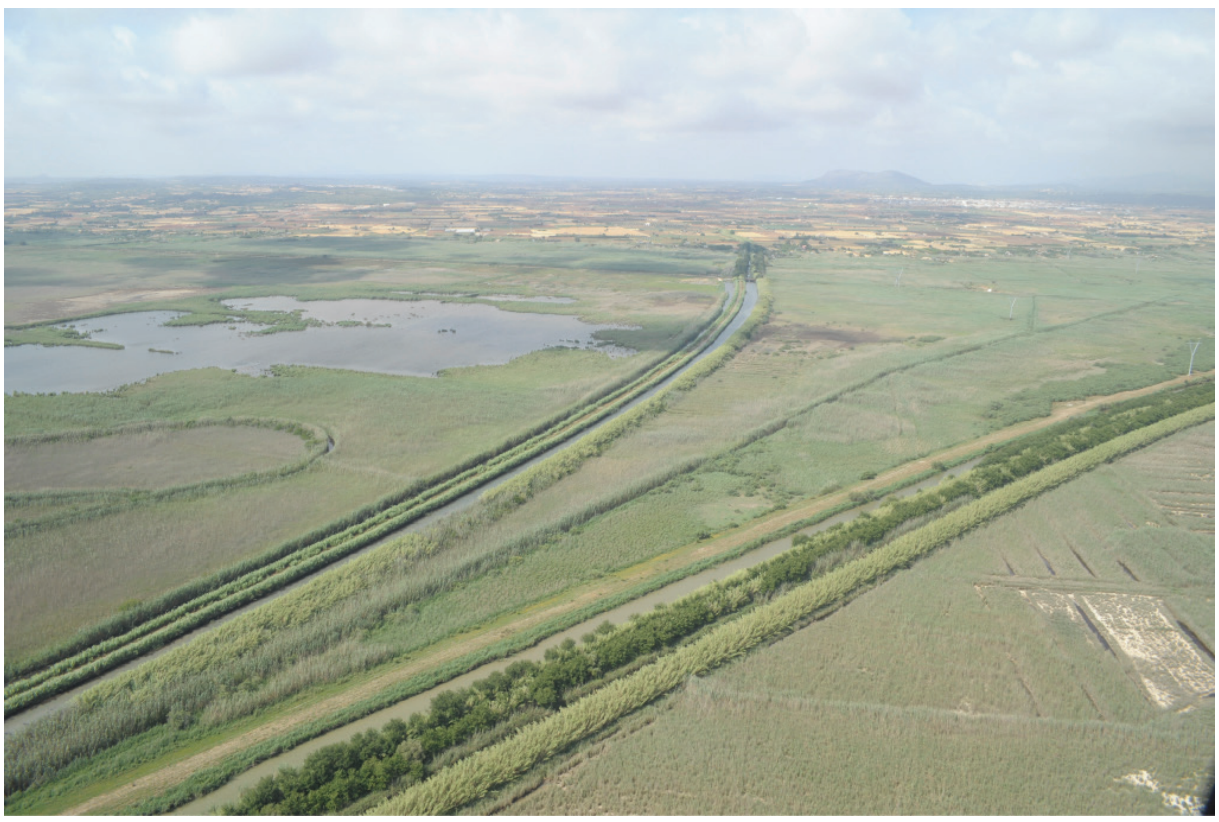

Figure 3. The Parc Natural de s'Albufera, Mallorca showing two main water channels entering from extensive agricultural zone beyond.

Figura 3. Ilustração da área de extensificação agrícola na zona ocidental do Parque Natural de Albufera (parte superior da figura).

Photo: courtesy of P.N. s'Albufera de Mallorca

Table 4. Catchment and whole Island (Mallorca) population growth, 1996-2003

Tabela 4. Representação da evolução demográfica na bacia hidrográfica e Ilha de Maiorca entre 1996 e 2003

\begin{tabular}{lll}
\hline Population Centre & $\mathbf{1 9 9 6}$ Census & $\mathbf{2 0 1 3}$ Census \\
\hline Alcúdia & 10,284 & 20,163 \\
\hline Muro & 6,060 & 6,977 \\
\hline Pollença & 12,945 & 16,200 \\
\hline Sa Pobla & 10,213 & 12,901 \\
\hline Santa Margalida & 6,789 & 12,243 \\
\hline MALLORCA & 609,150 & 864,763
\end{tabular}

source: INE (2014)

\subsubsection{Parc administration}

The lead authority in the management of the Parc is the Balearic Government's Conselleria de Agricultura, Medi Ambient $i$ Territori (Agriculture, Environment and Land) and it is one arm of this authority, the Directorate General of Natural Environment, Environmental Education and Climate Change (Direcció General de Medi Natural, Educació Ambiental i Canvi Climàtic), which has the greatest role. This body is responsible for all aspects of environmental conservation including biodiversity and natural resources, natural protected area management, terrestrial and marine ecosystems, landscape and forestry.
Another arm of the same body, its Secretariat General, is responsible for guarding and surveillance through its Environmental Agents Corp (Cos d'Agents de Medi Ambient) while the Directorate General of Hydric Resources (Direcció General de Recursos Hidrics) manages water resources through planning, control, rates for water usage and application of legal hydrological statutes. The Balearic Agency for Water and Environmental Quality (Agència Balear de l'Aigua i la Qualitat Ambiental, ABAQUA) is responsible for water purification plants and the Balearic Institute for Nature (Institut Balear de la Natura, IBANAT) provides the manpower for prevention and extinction of forest fires, forest management and conservation of natural protected areas.

Whereas main responsibilities come under the direct jurisdiction of the Balearic Autonomous Government, the Spanish State retains responsibility for the maritime and coastal public domain and its Ministry of Agriculture, Food and Environment is associated with coastal management through its Demarcation of the Balearic Islands Coasts (Demarcación de Costas de las Islas Balears).

Overall day to day activities are guided by the Parc Conservation Director whose small team of staff is assigned to specific tasks of maintenance and public use. A field biologist was employed to apply and monitor the condition and status of the Parc's habitats and wildlife until December 2012 when financial constraints ended the post.

The work programme responds to an annual plan drawn up by the Director in conjunction with his staff and a Parc Governing Council (Junta Rectora). The Junta Rectora incorporates representatives of the afore-mentioned management authorities as well as local municipalities and 


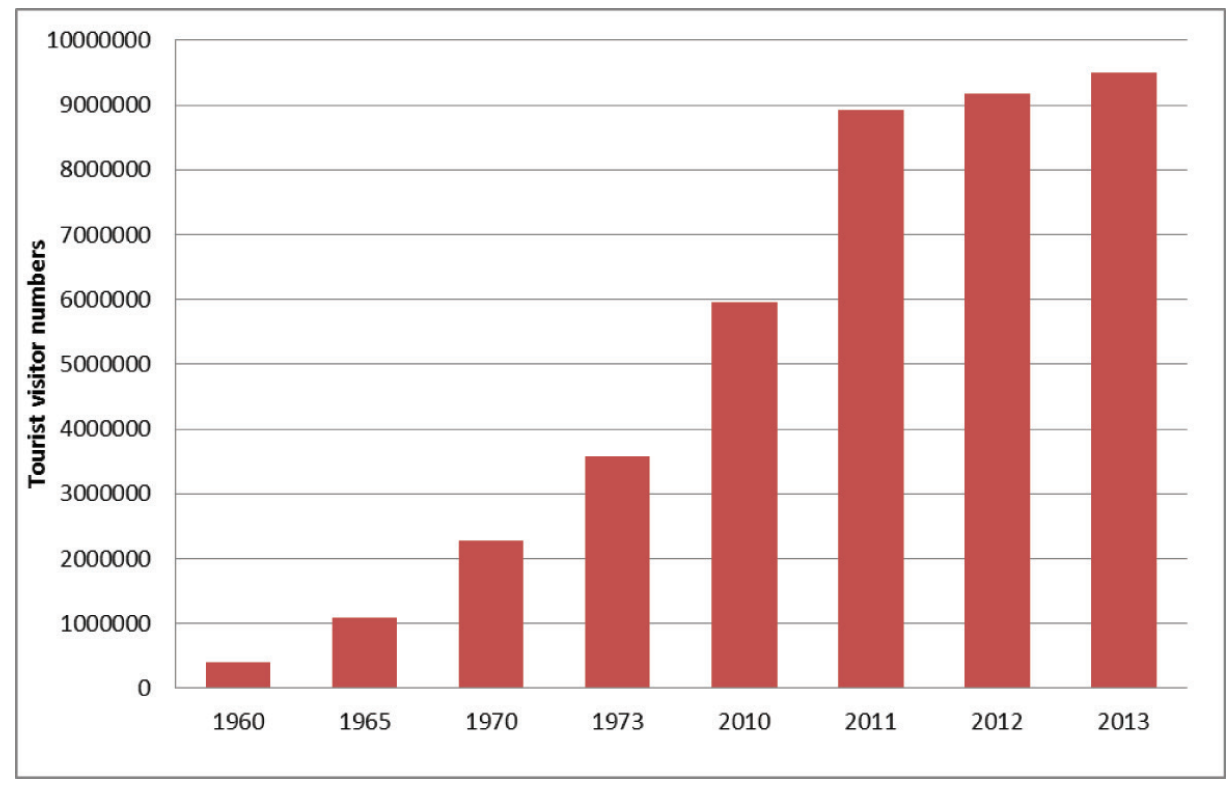

Figure 4. Visitor numbers for selected years to show trend of tourism growth, Mallorca, over the period 1960-2013. [1960-1973 data: Forcades \& Martorell (2003); 2010-2013 data: IBESTAT (2014)]

Figure 4. Número de visitantes em determinados anos de modo a evidenciar a tendência de crescimento turístico em Maiorca, no periodo entre 1960 e 2013.

conservation NGOs. This should provide a unified approach to management as well as ensuring the feasibility of the plan before it is passed to the Conselleria for approval.

\subsubsection{The facilities}

The Parc is open all year. Facilities include a reception area, exhibitions room and interpretation centre. The Casa del Parc has offices and other facilities for staff. In the early years of the project, accommodation for volunteers was basic. A generator provided electricity but was limited to four hours a day and teams of up to 20 were crammed into one large dormitory in the Casa del Parc. Teams are much better served now. The Parc has installed 24-hour mains electricity while the accommodation comprises four-bed dormitories complete with en suite facilities. The dormitories are part of the Casa de las Universidades, a purpose-built research block opened in 1999. The building includes a spacious laboratory, which is extremely well equipped thanks to a generous donation by the Bishop family in memory of the late Dennis Bishop, and is appropriately named the Bishop Lab.

\subsection{Project objectives and feedback to Parc}

The visionary Max Nicholson set the project some ambitious objectives (Earthwatch Europe, 1991). They appeared an immense challenge at the outset, but team TAIB has remained faithful to them all. They are:

a) to assemble full and detailed ecological data for the site and its surrounding area;

b) to provide data for evidence of local, regional and global change; c) to afford material for application in further research and reserve management at s'Albufera and in general conservation practice;

d) to provide resources for interpretive programmes and dissemination;

e) to serve as a focus for education in terms of training and creating environmental awareness and commitment.

It was determined that the first three years (1989-1991) should be dedicated to assembling the ecological data. In fact, this has proved to be a gradual, continuous process which has continued throughout the 25 years. At the same time, the team was already engaged in pilot studies for longterm monitoring in year one and launched some of the schemes in year two.

An absolute priority was to ensure good communication with the Parc. As the original scientific team was British, learning the local language was an important starting point. During fieldwork periods, the teams worked closely with Parc staff and this allowed an effective informal means of communication as well as providing a two-way flow of information. It was vital that Parc staff should feel included and valued and their thoughts, ideas and joint activities were important contributions to the development of the project.

A more formal feedback process was established through the provision of annual reports. These were necessary not only to communicate to a wider audience, including the environmental team at the Conselleria de Medi Ambient, but to allow for a more measured, analytical - albeit provisional - presentation of findings. Early reports comprised a limited run of bound copies, published by Earthwatch Europe. TAIB, however, wished to make these reports more widely 
accessible and has transcribed all its publications, from 1989 onwards, to its website (TAIB, 2014).

\subsubsection{Shaping of the studies}

The annual programme of work was inevitably shaped by the original objectives, though the themes and emphasis in any one year were often determined by the availability of researchers. TAIB also looked to respond to the immediate needs and interests of the Parc Directorate and staff, whether it was for scientific, educational or public awareness purposes. This was put on a more formal footing from 2005. A new system was put in place which identified investigations or actions deemed of priority to the Parc. The Parc Directorate proposed three priority tasks each year, though they were always finalised after consultation with TAIB scientists. The designated studies were different each year, thus greatly extending the remit of team TAIB. The team, however, was by then experienced and well established so was able to carry out the new tasks whilst still maintaining the vital long-term monitoring programme.

\subsubsection{Implementing the studies}

The ultimate goal of the studies was to seek an understanding of the key elements and processes which determine how the Parc's ecosystem functions as the basis for identifying impacts on the system and, if these are environmentally damaging, the means of resolution.

However, despite the involvement of some experienced scientists, the first few years were something of a step into the unknown. The first objective, to assemble full ecological data, did at least provide an early focus but it was a steep learning curve. In truth, that learning curve has hardly diminished, particularly as Parc policy has led the research group into new areas widening not only knowledge of the specific issue but a better understanding of its role in the ecosystem.

The scientific team at the time quickly formed a view that evaluation of global change was not possible at one site operating on its own, particularly one exposed to a number of local anthropogenic pressures, in line with international scientific opinion then (Moore, et al., 2001; Adger et al., 2009). It might be different now. Viewpoints are changing: the regional vulnerability approach to global change is becoming seen more often as a promising approach to increase our knowledge about these complex cause-andeffect relationships (Rosenzweig \& Wilbanks, 2010; Veraart et al., 2014). In addition, the digital revolution (internet) makes knowledge exchange between field sites much easier than in 1989.

Irrespective, it was clear that the project had a role in assessing local and regional impacts on the Parc and its environment. Designating a protected area is only the first step towards the conservation of the zone. It does not safeguard the area within from outside factors. Major issues were identified: nutrient enrichment and other pollution impacts; salt contamination of the aquifer due to over extraction of freshwater in adjacent agricultural areas; changes in the hydrology (Salamanca \& RodríguezPerea, 1999; Galimont et al., 2003; Candela et al., 2009); illegal release of non-indigenous fauna; losses of biodiversity through the impacts of beach tourism; urbanisation and other inappropriate developments in buffer zones adjacent to the Parc. Conservation management could not proceed without knowledge of their impacts and planning to mitigate them.

The only way to address these issues was first to investigate, then set up a long-term monitoring programme (Table 5). Certain investigation and monitoring tasks were achievable during the fieldwork periods but others required longer time periods or more prolonged study.

With limited resources, the Parc had insufficient staff availability to monitor more than the birds, meteorology and water quality (Table 6). TAIB took on a major role in extending that information pool. Birds are not the best subjects for environmental monitoring - at least at single sites - as they tend to react slowly to change. TAIB uses other bio-indicators to assess habitat and ecosystem quality. Biota such as submerged macrophytes and aquatic invertebrates are essential components of the system (Mitsch \& Gosselink, 1993; Scheffer, 1998); and their communities are ready indicators of the state of the water and of changes which are occurring (Veraart et al., 2004; Riddiford \& Férriz, 2009; Table 7). Long-term fieldwork has enabled us to increase our knowledge of the relationship between trends, seasonality and variability in water quality; and the ecological response (in this case aquatic communities and biodiversity).

In order to collect further sets of data, TAIB sought collaborations with outside organisations. Institutes such as the Tour du Valat Biological Station in France, University College London and the Universities of Newcastle and York in the UK sent researchers to investigate a range of ecological and conservation management issues. A particularly strong link was established with the Environmental Systems Analysis Group from Wageningen University, Holland. The Wageningen input was mainly in the guise of Masters studies and covered such key topics as bio-indicators for monitoring the impacts of agriculture and tourism (Veraart, 1999), water policies and water management (Cathala et al., 2002) and grazing as a management tool (Portero-Marti, 2004). In all, 22 theses have been generated through TAIB and include other relevant subjects such as anthropogenic impacts on the coastal environment (Whittingham, 1999), feeding ecology of Acrocephalus melanopogon in relation to fires (Taylor, 1993), niche partitioning in Ardeidae (Sargeant, 2002) and conservation priorities for dragonflies (Sato, 2002).

This partnership approach of Parc, collaborators and TAIB has led to an ever growing store of information on weather, water quality, birds, orchid populations, aquatic and terrestrial invertebrates, aquatic macrophytes, terrestrial plant communities, habitats and a range of human impacts. Baseline data have been collected for a wide range of plant and animal groups and published in a Biodiversity Catalogue (Riddiford, 2002), now expanded into a biodiversity database held at the Parc.

\subsubsection{The biodiversity database}

TAIB uses MS Access databases to maintain records of its long-term bird, moth, butterfly and dragonfly monitoring 
Table 5. Key elements of TAIB's surveillance and monitoring programme

Tabela 5. Elementos-chave do programa de monitorização e vigilância da TAIB

\begin{tabular}{|c|c|c|c|}
\hline Subject & Method & Frequency & Purpose \\
\hline Aquatic invertebrates & $\begin{array}{l}\text { Standardised sweep- } \\
\text { netting, water quality } \\
\text { sample sites }\end{array}$ & $\begin{array}{l}\text { Spring \& autumn } \\
\text { (formerly each year, now } \\
\text { converted to } 3-4 \text { year } \\
\text { intervals) }\end{array}$ & $\begin{array}{l}\text { Indicators for water quality; invertebrate } \\
\text { community structure } \& \text { health }\end{array}$ \\
\hline Submerged macrophytes & $\begin{array}{l}\text { Standardised sweep- } \\
\text { netting, water quality } \\
\text { sample sites }\end{array}$ & $\begin{array}{l}\text { Spring \& autumn } \\
\text { (formerly each year, now } \\
\text { converted to } 3-4 \text { year } \\
\text { intervals) }\end{array}$ & $\begin{array}{l}\text { Indicators for water quality; habitat condition; } \\
\text { monitoring change in face of salinisation, } \\
\text { eutrophication } \& \text { alien species (Cyprinus } \\
\text { carpio) impacts }\end{array}$ \\
\hline $\begin{array}{l}\text { Common birds of marsh } \\
\& \text { woodland }\end{array}$ & Transects & Spring \& autumn & $\begin{array}{l}\text { Population trends, habitat use, habitat } \\
\text { management }\end{array}$ \\
\hline Butterflies \& dragonflies & Transects & $\begin{array}{l}\text { Every } 10 \text { days, spring } \& \\
\text { autumn }\end{array}$ & $\begin{array}{l}\text { Population trends, habitat use, habitat } \\
\text { management }\end{array}$ \\
\hline Moths & Nightly light trapping & Spring \& autumn & $\begin{array}{l}\text { Population changes; species moving north } \\
\text { (climate change); detect alien species }\end{array}$ \\
\hline Coastal erosion & $\begin{array}{l}\text { Beach profiles; pioneer } \\
\text { vegetation monitoring; } \\
\text { public use studies }\end{array}$ & $\begin{array}{l}\text { Spring, summer } \& \\
\text { autumn (formerly annual } \\
\text { now at } 5 \text { year intervals) }\end{array}$ & $\begin{array}{l}\text { Public awareness; management actions; } \\
\text { monitoring success of management actions }\end{array}$ \\
\hline $\begin{array}{l}\text { Marshland orchid } \\
\text { Anacamptis robusta }\end{array}$ & Full census & $\begin{array}{l}\text { Annually from early May, } \\
1991-2010 \text {; monitoring } \\
\text { now by local University } \\
\text { (UIB) }\end{array}$ & $\begin{array}{l}\text { Improve management for conservation priority } \\
\text { species }\end{array}$ \\
\hline Thymelaea velutina & $\begin{array}{l}\text { Full survey; mapping; } \\
\text { soil \& vegetation } \\
\text { associations }\end{array}$ & $\begin{array}{l}\text { Spring 2008; repeat survey } \\
\text { planned, } 2018 \text { - earlier if } \\
\text { radical change noted }\end{array}$ & $\begin{array}{l}\text { Provide knowledge of distribution, soil } \\
\text { and habitat requirements for improved } \\
\text { management; conservation priority species } \\
\text { (endemism) }\end{array}$ \\
\hline Fish & $\begin{array}{l}\text { Inventory; trapping at } \\
\text { sample sites; historical } \\
\text { research from local } \\
\text { contacts }\end{array}$ & $\begin{array}{l}\text { Spring } \& \text { autumn } 2008 ; \\
\text { repeat surveys planned at } \\
5-10 \text { year intervals }\end{array}$ & $\begin{array}{l}\text { Inventory; fish community changes; habitat } \\
\& \text { water quality issues, management; status of } \\
\text { endemic form of Gasterosteus }\end{array}$ \\
\hline Diatoms & Sample sites & Pilot study, 2011 & $\begin{array}{l}\text { Indicators for wetland habitat conditions, } \\
\text { change (present \& past) }\end{array}$ \\
\hline $\begin{array}{l}\text { Vegetation community } \\
\text { recovery after fire }\end{array}$ & $\begin{array}{l}\text { Random sampling with } \\
\text { quadrats }\end{array}$ & $\begin{array}{l}\text { Annually } 1995-2004 \text {, then } \\
\text { repeat surveys at } 10 \text {-year } \\
\text { intervals }\end{array}$ & $\begin{array}{l}\text { Provide knowledge for habitat and rare plants } \\
\text { management }\end{array}$ \\
\hline $\begin{array}{l}\text { Impacts of livestock in } \\
\text { dune grassland }\end{array}$ & $\begin{array}{l}\text { Random sampling with } \\
\text { quadrats }\end{array}$ & $\begin{array}{l}\text { Repeat surveys every } 2-3 \\
\text { years }\end{array}$ & $\begin{array}{l}\text { Monitor plant diversity in livestock exclusion } \\
\text { zone; habitat management }\end{array}$ \\
\hline
\end{tabular}

Note: table indicates preferred time scales; the voluntary character of TAIB means that flexibility is needed to meet the availability of appropriate scientists. The data, however, are sufficient to determine trends and interactions between different parts of the ecosystem. 
Table 6. Environmental monitoring activities undertaken by Parc staff

Tabela 6. Atividades de monitorização ambiental desenvolvidas pela equipa do Parque Natural.

\begin{tabular}{|c|c|c|c|}
\hline Subject & Method & Frequency & Purpose \\
\hline Water quality & Fixed sample sites & Monthly & $\begin{array}{l}\text { Monitor eutrophication, salinisation; } \\
\text { provide hard data for hydrological } \\
\text { planning }\end{array}$ \\
\hline Meteorology & $\begin{array}{l}\text { Automatic Weather Station (see } \\
\text { note 1) }\end{array}$ & Constant updates & $\begin{array}{l}\text { Baseline information; reference for } \\
\text { weather events, climate change etc. }\end{array}$ \\
\hline Birds & $\begin{array}{l}\text { Fixed point counts; waterfowl } \\
\text { breeding productivity; mid-winter } \\
\text { waterfowl survey; migration log }\end{array}$ & $\begin{array}{l}\text { Daily observations; mid- } \\
\text { winter count part of } \\
\text { international wildfowl census }\end{array}$ & $\begin{array}{l}\text { Population change; provide knowledge } \\
\text { of distribution and habitat requirements } \\
\text { for improved management; } \\
\text { conservation priority species }\end{array}$ \\
\hline
\end{tabular}

Note 1: http://www.mallorcaweb.net/salbufera/meteo/davis_albufera.htm

Table 7. Submerged macrophyte and invertebrate indicators for the quality of the aquatic environment at s'Albufera de Mallorca.

Tabela 7. Indicadores derivados de indices de macrófitos submersos e invertebrados para a avaliação da qualidade do ambiente aquático na Albufera em Maiorca.

\begin{tabular}{|c|c|c|c|}
\hline Species & Status & Indicator for & Parameters \\
\hline \multicolumn{4}{|c|}{ Flora } \\
\hline Cymodocea nodosa & Potential colonist of coastal lagoons & Hypersaline conditions & Presence \\
\hline Ceratophyllum demersum & Decreasing & Rehabilitation of freshwater & Re-colonisation of former sites \\
\hline Lemna minor & $\begin{array}{l}\text { Now restricted to areas on western border } \\
\text { of Parc }\end{array}$ & Low salinity & Presence \\
\hline $\begin{array}{l}\text { Rorippa nasturtium- } \\
\text { aquaticum }\end{array}$ & Restricted to Síquia des Polls & Oligohaline water & Presence \\
\hline Typha domingensis & Dominant in some canals & Eutrophication & Presence in dense stands \\
\hline Typha angustifolia & Abundant in some canals & Eutrophication & Presence in dense stands \\
\hline Polygonum salicifolium & Good population, Siquia des Polls & Low phosphate levels & Presence \\
\hline Sparganium erectum & $\begin{array}{l}\text { Only certain recent record in ses Veles } \\
\text { (outside Parc) }\end{array}$ & Mesotrophic water & Presence \\
\hline \multicolumn{4}{|c|}{ Algae: Chlorophyta } \\
\hline Chaetomorpha & Widespread, increasing & $\begin{array}{l}\text { Increased salinity combined } \\
\text { with eutrophication }\end{array}$ & $\begin{array}{l}\text { Presence and abundance; increased } \\
\text { distribution }\end{array}$ \\
\hline Enteromorpha intestinalis & Widespread on surface of water bodies & Eutrophication & Presence and dominance levels \\
\hline Cladophora & Dominant in places & High phosphate/nitrate levels & Presence/abundance \\
\hline Spirogyra & Abundant and widespread & Anoxic conditions & Presence/abundance \\
\hline \multicolumn{4}{|c|}{ Mollusca: Pelecypoda } \\
\hline Rudicardium tuberculatum & $\begin{array}{l}\text { Common and widespread in hypersaline } \\
\text { waters }\end{array}$ & $\begin{array}{l}\text { Hypersaline conditions, } \\
\text { including through rising sea } \\
\text { levels }\end{array}$ & Presence; colonisation of new areas \\
\hline \multicolumn{4}{|c|}{ Mollusca: Gastropoda } \\
\hline Ovatella myosotis & Brackish water and salt marshes & Brackish conditions & $\begin{array}{l}\text { Presence/abundance; increased } \\
\text { distribution }\end{array}$ \\
\hline Amnicola similis & In decline & Unpolluted waters & Distribution and abundance \\
\hline \multicolumn{4}{|c|}{ Crustacea: Cladocera } \\
\hline Daphnia mediterranea & $\begin{array}{l}\text { Freshwater but with tolerance of salinity } \\
\text { exceeding } 3.5 \mathrm{~g} / \mathrm{l}\end{array}$ & Saline intrusion & Presence \\
\hline \multicolumn{4}{|c|}{ Insecta:Lepidoptera } \\
\hline Paraponyx stratiotata & $\begin{array}{l}\text { Captures previously regular, now } \\
\text { infrequent }\end{array}$ & Submerged macrophyte cover & Presence/abundance \\
\hline
\end{tabular}


studies. A system is now being developed to extend the information system to all biota. The initial task was to capture and bring to a central source the various and disparate sets of data held by the project. But the main objective from the very start was to provide a ready and immediate resource for the Parc and other associated parties to guide and enhance conservation management. A baseline capture of all biota recorded at s'Albufera has been achieved. The next stage is to complete the task of relating those data to issues such as status, ecology, conservation value and management needs through a quick and easy access system. Tables 8 and 9 present two examples of the types of information already available. The database uses a simple yes/no format for these criteria so the requisite species can be determined at a glance and extracted in report form. The database has allowance for a range of criteria (e.g. population trends, endemisms, indicator species, etc.), a number of which are still in development. The database is open and available for Parc staff and TAIB scientists who also act as moderators for others wishing to use the resource. Plans to make the database information more widely available through international platforms such as the MedWet Web Information System (MedWet, s/d) and the Europe-wide ALTER-Net (A Long-Term Biodiversity, Ecosystem and Awareness Research Network) (ALTER-Net, s/d) have been stymied so far through lack of manpower and financial means to achieve such a major task.

\subsubsection{Outreach}

TAIB's principal activity is to gather information which can advise and guide biodiversity conservation in the Parc. However, its remit extends beyond the Parc in many ways. Regionally, team members have been active in socioeconomic studies of the catchment area (Royo et al., 2010; Férriz, 2012, 2013), ecological studies in other protected areas of Mallorca and biodiversity studies in Menorca, Ibiza and Formentera (Honey et al., 2003; Honey \& Riddiford, 2003; Férriz et al., 2006). Further afield, the training given to protected area managers has extended the reach of TAIB internationally. Indeed, TAIB team members have taken their capacity building and conservation management skills to various countries of sub-Saharan Africa and the southern and eastern rim of the Mediterranean. Much of the basis for this training derives from the key MedWet publication, Monitoring Mediterranean Wetlands (Tomàs-Vives, 1996). TAIB led a pilot study to test the monitoring framework and process (Riddiford \& Mayol, 1996); and TAIB principal investigator, Nick Riddiford, acted as scientific editor for the publication.

The Biodiversity Catalogue (Riddiford, 2002) was another means of meeting an original objective: to afford material for application in further research and reserve management. These technical documents were followed by publications designed to help members of the general public get the most out of their visit: a guide to the plants of the Parc's tracks, marsh and meadows (McLennan \& Newbould, 2003); guides to the common birds of s'Albufera (Owens, 2007; Owens \& Vicens, 2009) and to the common butterflies and dragonflies of the Parc (TAIB, in prep.). The plant guide was innovative in its approach, using colour and symbols but minimum text, thus making the guide accessible to all
Table 8. Alien Species per Group recorded at s'Albufera, source TAIB Biodiversity Database.

Tabela 8. Espécies invasoras registadas na Albufera, por Grupo. Fonte: TAIB Biodiversity Database.

\begin{tabular}{lrrr}
\hline Group & Biota & Exotics & \% Exotics \\
\hline Higher Plants & 714 & 9 & 1.26 \\
\hline Bryophytes & 66 & & 0 \\
\hline Algae & 202 & & 0 \\
\hline Fungi/Lichens & 288 & & 0 \\
\hline Bacteria & 3 & & 0 \\
\hline Birds & 307 & 32 & 10.42 \\
\hline Mammals & 28 & & 0 \\
\hline Amphibia & 2 & & 0 \\
\hline Reptiles & 13 & 6 & 46.15 \\
\hline Fish & 39 & 2 & 5.13 \\
\hline Molluscs & 118 & 1 & 0.85 \\
\hline Insects & 1995 & 3 & 0.15 \\
\hline Arachnids & 113 & & 0 \\
\hline Centipedes & 2 & & 0 \\
\hline Crustacea & 75 & 1 & 1.33 \\
\hline Rotifers & 23 & & 0 \\
\hline Other Invertebrates & 45 & 1 & 2.22 \\
\hline & & & \\
\hline TOTALS & $\mathbf{3 8 9 0}$ & $\mathbf{5 5}$ & $\mathbf{1 . 4 1}$ \\
\hline
\end{tabular}

nationalities irrespective of language. Most important of all, the guides are aimed at the non expert, although the plant guide particularly is used by expert botanists as well.

Publications are expensive, so TAIB has turned to the internet for dissemination, education and public awareness. A great deal of non-technical as well as technical information is available on TAIB's website (TAIB, 2014); and in 2012 members of the scientific team established a website (Associació TAIB, 2014) whose primary aim is to make the general public aware of moths and butterflies as part of an ecosystem shared by humans and influenced by human activities. The site uses Lepidoptera to demonstrate how small adjustments by people, as well as bigger actions by society, can reduce negative impacts on the populations and well-being of these and other overlooked members of the ecosystem. The concept of conservation begins with the young. This project also includes some entertaining and informative posters specially designed for schoolchildren.

Mallorca has a very good environmental education system with teacher-naturalists operating in several protected areas including s'Albufera. Over the years, TAIB has worked closely 
Table 9. Conservation Status of Birds per Order recorded at s'Albufera, source: TAIB Biodiversity Database.

Tabela 9. Estatuto de conservação de Aves registadas na Albufera, por Ordem. Fonte: TAIB Biodiversity Database.

\begin{tabular}{|c|c|c|c|c|c|}
\hline Order & Biota & $\begin{array}{c}\text { Habitat } \\
\text { Directive }\end{array}$ & $\begin{array}{r}\text { Birds } \\
\text { Directive }\end{array}$ & $\begin{array}{r}\text { Spanish } \\
\text { National } \\
\text { Catalogue }\end{array}$ & $\begin{array}{c}\text { Balearic } \\
\text { Catalogue }\end{array}$ \\
\hline Anseriformes & 35 & 14 & 2 & 3 & \\
\hline Apodiformes & 3 & & & & \\
\hline Caprimulgiformes & 1 & & & & \\
\hline Charadriiformes & 66 & 18 & 16 & 3 & 2 \\
\hline Ciconiiformes & 8 & & 2 & 1 & \\
\hline Columbiformes & 4 & 4 & & & \\
\hline Coraciiformes & 4 & & 1 & & \\
\hline Cuculiformes & 2 & & & & \\
\hline Falconiformes & 27 & & 12 & 6 & \\
\hline Galliformes & 7 & 1 & & & \\
\hline Gaviiformes & 1 & & & & \\
\hline Gruiformes & 13 & 3 & 1 & 1 & 1 \\
\hline Passeriformes & 105 & 7 & 1 & 7 & \\
\hline Pelicaniformes & 12 & & 7 & 3 & \\
\hline Phoenicopteriformes & 2 & & 1 & & \\
\hline Piciformes & 1 & & & & \\
\hline Podicipediformes & 4 & & & & \\
\hline Procellariiformes & 2 & & 1 & 2 & \\
\hline Psittaciformes & 5 & & & & \\
\hline Strigiformes & 5 & & 1 & & \\
\hline TOTALS & 307 & 47 & 45 & 26 & 3 \\
\hline
\end{tabular}

with the educators, responding to requests for material, information and advice and holding joint workshops with the educators and volunteers as part of the capacity building programme. It is a matter of pride to TAIB that a number of the teacher-naturalists from the Balearics have progressed through TAIB training as previous participant volunteers.

\subsubsection{Feeding into wider local issues}

Effective conservation management of s'Albufera requires the involvement and cooperation of a range of stakeholders, both within and outside the Parc. Tourist developments and agricultural systems immediately outside the Parc boundaries have human and environmental implications for the management of the Parc's ecosystems and biodiversity
(Veraart, 1999; Veraart et al., 2004; Férriz, 2010, 2012). Interacting with stakeholders is therefore a major part of the Parc Directorate's work. This is achieved through its Junta Rectora but also through regular communication. TAIB's contribution was originally indirect, providing comments, advice and recommendations which were then pursued by the Parc or the Conselleria. However, TAIB has taken an increasingly pro-active role as knowledge and experience evolved. This has been achieved through Project Open Days, involvement in the Parc's own Activity days, cooperative links with the local conservation NGO (Grup Balear de Ornitologia i Defensa de la Naturalesa, GOB), the University of the Balearic Islands, the Mediterranean Institute for Advanced Studies (IMEDEA) and other bodies; 
and, since 2009, TAIB has direct representation on the Junta Rectora, currently Laura Royo of Associació TAIB.

The project has also sought the comments and opinions of a range of key stakeholders and administrative bodies on specific, conservation management related issues. This was first achieved through the activities of the Wageningen Masters students whose focus on various elements of the Parc's functions and values necessarily took into account wider catchment issues (e.g., Borggreve, 1997; van der Perk, 1997; Feenstra, 1998; Veraart, 1999; Cathala et al., 2002; and see de Groot, 1992 and de Groot et al., 2002 for the functions and values concept approach). Whereas team TAIB is limited in what it can achieve during fieldwork sessions, members of the locally established Associació TAIB have taken the lead in a series of initiatives to engage with local stakeholders. In the coastal zone, Royo used TAIB team members in a dune restoration programme which included interviewing tourists about their use of the beach and their views on actions to protect dune erosion, whilst the same study worked with the various coastal management agencies to initiate appropriate restoration measures (Traveset et al. 2006). Stakeholders played an integral part in the information gathering process for TAIB studies on the agricultural systems and tourism developments immediately outside the Parc boundaries (Veraart, 1999; Whittingham, 1999; Stuip, 2001; Veraart et al., 2004; Royo et al., 2010; Férriz, 2012, 2013) which have impacts on the ecology of the Parc and, by association, the Parc biodiversity. TAIB specialists in hydrology and aquatic ecology participated in catchment, regional and national meetings discussing implementation of the EU's Water Framework Directive; and have acted as consultants for the currently evolving catchment-wide hydrological plan.

Seeking the views of local stakeholders was an important element of Associació TAIB's multi-criterial ecosystem services assessment of the area (Royo et al., 2010). The assessment was accompanied by recommendations for future sustainability of the Parc and its adjacent area and was undertaken to provide the Parc with the socio-economic background it will need to prepare a future Pla d'Ordenació de Recursos Naturals (Natural Resource Plan). In another study, Férriz (2012) undertook a socio-ecological diagnosis of the Pla de sa Pobla (Sa Pobla Plain) agricultural zone, which incorporated interviews with experts, key people from the town of Sa Pobla and many of the people working in local agriculture. The main objective was to capture the relationship between agriculture and natural resources conservation in order to establish the main causes of negative impacts and seek common ground for means of resolution which change these to positive.

Consultation with stakeholders brings with it an environmental awareness element. This is an ongoing conversation towards a land management system which addresses the role of farmers and other stakeholders in good stewardship of natural resources and the landscape. Such a utopic goal will not be achieved overnight but the engagement process has already produced some interesting responses. As part of a study into changes in the fish community of s'Albufera (Riddiford \& Fernández, 2009), a workshop was organised in a local town with fishermen who had traditionally fished in the wetland. They were not only extremely helpful in providing a historical perspective to fish population changes, particularly for eels Anguilla anguilla, but delighted their opinion was sought. Team TAIB interactions with local people and visitors from elsewhere (e.g., Traveset et al., 2006; Royo et al., 2010; Férriz, 2010, $2012,2013)$ have revealed a keen interest in the well-being of s'Albufera and acknowledgements of the need to achieve an environmental balance.

\section{DISCUSSION}

\subsection{Ecosystem services provided by the Parc}

Increasingly, the perspective of the ecosystem services (Costanza et al., 1997) provided by the Parc to the local populace and to society in general has determined the direction of many of TAIB's studies, in particular assessing the impacts of human activities on these services. The initial intent was to provide the scientific data to guide the Parc management team in maintaining and enhancing the environmental qualities of the site. As the studies developed it became clear that the information accruing not only improved knowledge of ecosystem functioning, it also revealed a number of issues which went far beyond pure environmental concern. Using various groups of biota as indicators of the state of the ecosystem, it became evident that trends and changes were emerging (e.g. Veraart et al., 2004); and these had potentially serious impacts of environmental, social and economic relevance.

Environmental impacts on the Parc included the loss of biodiversity through eutrophication and changes in salinity levels. Nutrient intrusion from farmland, phosphates escaping from water purification plants, over abstraction of water from the aquifer all challenge the tolerance levels of biota adapted to pre-modernisation eras. These accumulating pressures induce changes in ecological processes and biodiversity in the wetland despite measures of protection and conservation.

These impacts highlight issues of wider concern. Nutrient intrusion indicates injudicious use of agricultural fertilisers. The crops use what they need and the excess is absorbed into the ground water (e.g., Carton et al., 2008; Daniel et al., 1998). Chemicals are expensive and over-use is the equivalent of throwing money directly into the canals. It can also lead to raised nitrate levels in water taken for human consumption. Indeed, in Sa Pobla, the agricultural town to the west of the Parc, people avoid drinking it even though water from the aquifer is treated by an expensive inverse osmosis station that reduces nitrate levels in drinking water to the maximum $50 \mathrm{mg} / \mathrm{l}$ permitted by the European Water Framework Directive; they prefer to buy bottled water or drink from traditional wells in their houses (Férriz, 2012). Phosphate intrusion indicates that wastewater treatment plants built prior to the growth in tourism, and the summer population explosion which goes with it, are no longer fit for purpose.

The Parc Natural de s'Albufera is an important buffer between the sea and Mallorca's most productive farmland area. Expanding tourism and the intensification of agriculture place considerable pressure on freshwater resources. A freshwater deficit in the groundwater leads to an 
imbalance reflected in increasing salinity levels and gradual saline penetration inland from the coast. This process has major long-term implications for the local area and its socioeconomic well-being (Royo et al., 2010)

The height of reeds Phragmites australis bordering the Parc canals, reaching 7 to 8 metres in places, is a clear indication of the role they play in absorbing nutrients entering the Parc. Nevertheless, a portion of the nutrient-rich water passes directly to the sea where it can impact on the important seagrass Posidonia oceanica beds of the adjacent Alcudia Bay (Whittingham, 1999). Nutrients promote rapid growth of filamentous algae and phytoplankton, threatening the slow growing Posidonia through smothering and by reductions in light penetration. This is more than just an environmental issue. The Posidonia beds are a refuge and nursery area for commercial fish, are home to biota which provide an average of $70 \%$ of the sand for Balearic beaches (Rodríguez-Perea et al., 2000), create a buffer and re-cycle sand lost from beaches, and act as a brake to waves during onshore storms, thus protecting the beaches and coastline from erosion (McRoy \& Helfferich, 1977; Duarte \& Chiscano, 1999; Rodríguez-Perea et al., 2000; Traveset et al., 2006). Nutrient enrichment can lead to toxic plankton blooms (e.g. the red tides of the Po Delta and northern Adriatic), which is not a risk the tourism-based municipalities around Alcudia Bay should be willing to take (Facca et al., 2014; Fonda Umani et al., 1989; Zingone, 2010).

Most of the wetland area lies at 0 to $2 \mathrm{~m}$ above sea level. It is protected from inundation by a band of coastal dunes. These dunes line much of the bay but only a small portion has escaped development and been incorporated into the Parc. They are the last stronghold for an endemic plant and contain other key habitats, plants and animals (Férriz, 2009). But they also serve a socio-economic purpose as a buffer against inundations which would otherwise take the sea water well inland. The dunes have developed in three phases over the last 12,000 or so years, with the final stage still developing into the $20^{\text {th }}$ century (Gelabert et al., 2002). That building phase ended with the growth of tourism, and erosion of the fore dune has reversed the process (Servera et al., 2009). The dunes are $500 \mathrm{~m}$ wide but losses of up to 2 $\mathrm{m}$ width during storms demonstrate the vulnerability of this buffer in the longer term.

An almost continuous band of prickly juniper Juniperus oxycedrus macrocarpa lines the fore dunes. Erosion of the dune face where it meets the sea has accelerated in recent years (Rico, L., unpublished). Without the presence of Juniperus oxycedrus macrocarpa, the extent of this erosion would have been even more severe. The roots of Juniperus oxycedrus macrocarpa function as a consolidating agent for the sand, for the establishment of other vegetation and for holding the dunes together (Muñoz-Reinoso, 2004). With their roots exposed, however, there is considerable dieback of this band (Férriz, 2009) and low capacity for recovery (Traveset et al. 2006). Prevention of further damage to this band is not only a conservation issue but has practical implications for the long-term maintenance of the dunes and beach.

Much of the problem lies with current management of the beach, which is tourism-orientated. Mechanical cleaning of the beach removes cast Posidonia, which would trap and retain the sand, also removes quantities of sand and changes the profile of the beach from undulating to smooth. The impact derived from tourist use has led to the Posidonia meadows retreating seawards (Whittingham, 1999). With Posidonia absent from shallow inshore waters, its role in the formation and protection of beach and dunes is much reduced. Some remedial measures have been taken recently but a full management programme would recognise the long-term importance to society of maintaining the dune system in good order (Traveset et al., 2006).

Implications for society in the region extend to the role of the Parc as a rain-fed infiltration and buffering area for freshwater. The Parc Directorate is very sensitive of the hydrological needs of the entire system and makes every effort to manage the hydrological balance (both groundwater and surface water) for the benefit of the entire region. The main management purpose is to maintain the natural Mediterranean pattern of gradual drying out during the summer months and recharge at other times of year. However, during periods of prolonged drought the Parc makes every effort to retain freshwater, aware that the aquifer extends inland to the agricultural land and beyond, whilst after heavy periods of rain it channels as much of the excess as it can directly to the sea to prevent or reduce inundations extending landwards into the periphery.

\subsection{Socio-economic importance of the Parc}

The socio-economic relevance of management, whether to prevent dune erosion or to maintain a healthy water balance, is often overlooked or is not even perceived (Royo et al., 2010). Such actions come under the umbrella of ecosystem services. Nature tourism is another ecosystem service which has considerable socio-economic value. The Parc registers between 55,000-65,000 visitors per year (2003-2009 Parc annual reports). That figure is an underestimate because studies have revealed that at least $40 \%$ do not report to reception to register. The actual figure is more likely to be in the range 105,000-120,000 (B. Perelló pers. comm., 2014).

Being close to a major tourist area, the Parc adds to the diversity of choice for tourists during the summer months particularly during cloudy days when the beach seems less attractive; and visits are free! It is in spring and autumn that the value of this protected area is at its greatest. S'Albufera is famous throughout Europe and beyond amongst birdwatchers (Owens \& Vicens, 2009; Rebassa et al., 2009). It is known as a "hot spot" for rare birds, for spectacular numbers and diversity. The best times are spring and autumn, when migrant birds add to the interest. The birdwatchers and other naturalists come then, bringing income to the area and, most importantly, extending the tourist season for the accommodation outlets and supporting services.

The Parc manages visitors effectively to ensure that they can view the birds well without causing disturbance to the wildlife. Management extends to creating the conditions and habitats that the birds require. Long-term monitoring is a necessary part of that process. It provides a cost-effective early warning system so that measures can be put in place to address problems for the benefit of the ecosystem generally and, consequently, the birds which draw so many visitors to s'Albufera and Mallorca. 
The current economic monetary system is an inappropriate tool for measuring biodiversity because it fails to take into account non-market values (de Groot, 1992; Gowdy, 1997; Costanza et al., 1997; de Groot et al., 2002). This is a real challenge for biodiversity conservation. TAIB has identified a role in investigating more deeply the services that s'Albufera and its ecosystem contribute to human wellbeing in order to raise the profile of the non-market values of biodiversity, particularly in terms of public perception and awareness of the benefits these services bring.

\subsection{Recent focus of monitoring and research}

TAIB's biodiversity studies began as a data collecting exercise, concentrating on the most popular and better known groups. One such study, focusing on moths attracted to light, has turned into one of the longest monitoring studies in the Mediterranean. Research has revealed important populations of rare moths, such as Pelosia plumosa and Eilema rungsi, which are reliant on old reed beds. This habitat type is itself a rarity in the Mediterranean as reed beds are often kept in an early stage through burning and grazing. Studies of Odonata (dragonflies and damselflies) have also demonstrated the importance of habitat quality, and generated conservation management recommendations for this attractive insect group (Sato \& Riddiford, 2008).

In recent years studies have extended to other groups including flies (Diptera), bees and wasps (aculeate Hymenoptera) and aquatic beetles (Coleoptera). This has led to many exciting discoveries and expansion of knowledge for poorly studied groups in the western Mediterranean. For instance, the Diptera studies added 330 species to the Balearic list in just one year, 99 of which were also additions to the Iberian list published by Carles-Tolrá (2002); sixteen of these were from a single family, Chloropidae (Ebejer, 2006). New fauna for Europe include several moth species, most notably males of a species previously known only from females in West Africa (Fibiger \& Agassiz, 2001), and the aquatic beetle Cyphon lindbergi (Foster \& Riddiford, 2011). A bat, Pipistrellus pygmaeus, now known to be commonplace, was confirmed as new to Mallorca (Green \& Riddiford, 2009). A lot of publicity has been given to the role of bees and their allies as pollinators in light of recent global declines. The hymenopteran studies have revealed the importance of s'Albufera for this group. The list of aculeates currently stands at over 200, including the re-discovery of the Mallorcan endemic Miscophus belveriensis, not seen since it was described in 1960 (Baldock, 2014).

\subsection{Alien species}

A number of additions will be naturally occurring species previously overlooked. However, an increasing number can be considered newcomers to Mallorca. These fit into two categories: species moving north from Africa and introduced species.

Many of the species moving north are from North Africa but others probably arrive from farther south. These arrivals often coincide with spells of Saharan dust falling on Mallorca; Honey et al. (2007) postulated that they are swept up by rapidly rising air in extreme conditions of heat south of the Sahara and carried northwards on the consequent winds. Thus their arrival may have been through inadvertent rather than intentional migration. This type of arrival relates to a singular climate event but the continued arrival, sometimes in increasing numbers, of others may be the result of expanding populations related to climate change.

This has implications for society. Names such as the Egyptian bollworm (Earias insulana), African cotton leafworm (Spodoptera littoralis) and maize wainscot (Sesamia nonagrioides) highlight the risks some of these biota could hold for agriculture north of the Mediterranean.

TAIB's long-term light trapping programme has detected an alarming growth in the occurrence and numbers of introduced species. The tomato leaf miner Tuta absoluta challenged our identification skills when first caught in 2008 but by November 2013 was consistently the commonest moth in the trap. A similar pattern was recorded for the citrus flatid planthopper Metcalfa pruinosa. The tomato leaf miner originates from South America and can devastate tomato crops (Desneux et al., 2010; van der Straten et al., 2011). Metcalfa is from North America where it causes problems amongst fig, grape, citrus and other fruit crops (Bagnoli \& Lucchi 2000; Pons et al., 2002). In 2011 TAIB caught the first harlequin ladybird Harmonia axyridis for the Balearic Islands. In 2013 it caught three more - in one night. This beetle, originally from eastern Asia, can do enormous damage as it emits a distasteful liquid which taints fruit and wine and, when large numbers overwinter in houses, can drive the occupants out with the same noxious smell (Koch, 2003; ISC, s/d).

The IUCN recognises invasive species as the second most important cause of biodiversity loss after habitat destruction (CBD, s/d). Invasive species have also been identified as one of the leading and most rapidly growing threats to food security and animal health (ISSG, s/d). All administrations and especially those of islands should be aware of the potential dangers of introductions not just for the biodiversity - which on small islands often includes important endemisms - but also for the unforeseen social and financial impacts on their citizens.

\subsection{Preparing future managers and communicators}

For administrations to act, they must know about the consequences and the steps required to put things right. TAIB annual reports take on the responsibility of making this information available by detailing the issues and their risks; and by making recommendations regarding the measures required to manage those risks. These annual reports, complete with the recommendations, are also made available to the public at large through TAIB's website (TAIB, 2014).

This is just the beginning of the dissemination process. Communication needs communicators: this is where the capacity building aspect dovetails comfortably with the field science. By 2012 participants had taken part from 50 countries. For all, it was an introduction to the value of knowledge, as a continuous process, not just in protected area management but in conveying that information to others. 
The courses seek to instil in the participants a confidence in the application of field methodologies and other biodiversity conservation measures, skills which they can take back to their own area or country. But the dissemination element is never lost from view. TAIB's success in this area was demonstrated during a course focused entirely on the practicalities of environmental education, set up for educators from the Cape Verde Islands. The course included workshops with staff from the various environmental education outlets active in Mallorca, governmental and independent; it was noteworthy that a large proportion had passed through a TAIB capacity building course prior to entering into the environmental education system.

TAIB's policy of integrating local volunteers into the training process has seen impressive dividends. A stream of young Balearic and Spanish post graduates has passed through the project. A considerable number are now working in conservation and the environment, including at the international level, and making a difference in safeguarding the natural world. Many of the personnel now working in Balearic conservation circles had their first environmental training experience with TAIB.

This mix of local people with those from abroad, and students still to graduate with those already involved in conservation management, works extremely well; and it extends to TAIB's scientific team. A team that was largely British in 1989 is now a mix of international experts and talented home-grown scientists from the Balearic Islands and mainland Spain who have graduated from University and from the capacity building experience with TAIB. These graduates came with large amounts of enthusiasm and willingness to learn but were generally inexperienced and without in-depth knowledge of environmental field research. One of the greatest satisfactions for the scientific team, and one which has drawn members to return time and again, has been to witness these graduates build their capacity and skills: a number are now experts in their own right.

Some have joined the scientific team, making TAIB a balanced combination of local and international expertise. This integrated approach has revolutionised knowledge of the Parc's important wetland and dune ecosystems; and of the rich biodiversity of the Parc and its adjacent catchment. Incorporating local scientists has many benefits, not least the availability of local team members to undertake studies or collect data at times of the year outside the fieldwork periods. Most important of all, it establishes a local identity for the project.

\subsection{Citizen science}

The use of volunteers to help the information gathering process for biodiversity conservation has a long tradition. Bodies such as the British Trust for Ornithology have organised national surveys and monitoring schemes for more than 70 years (BTO, s/d) and countless other national organisations now do the same (e.g., Vliet et al., 2013). Protected areas too work increasingly with volunteers for specific tasks, including routine monitoring (e.g., RSPB, 2014; SEO, s/d). Volunteers also participate in regional and site specific environmental data gathering tasks, but normally restricted to a narrow, easy to recognise suite of biota such as birds, butterflies or moths (e.g., AEN, 2009). In this way, once basic skills have been taught, surveys can be conducted with minimum involvement and intervention by scientists. There is evidence of greater scientist commitment to the volunteer sector in recent years (e.g., NHM, s/d). Models also exist for capacity building in environmental management (Costa et al., 2013; Echevarría et al., 2013) though few base the training module in the field rather than mostly in the classroom or workshop.

TAIB Project S'Albufera remains novel in both its approach and its extent. It does not need to stand alone. The visionary Max Nicholson, initiator of major international conservation bodies such as the World Wide Fund for Nature (WWF, 2003), intended s'Albufera to be the forerunner of a concept which he hoped would be extended to protected areas throughout the world. The test of his concept has been this project and is described here in the hope that others will derive inspiration from it.

\section{CONCLUSIONS}

The aim of this paper is to put forward a cost effective integrated participative model for collecting the data required to support environmental management in a protected area. It also demonstrates the absolute need for long-term studies to understand the ecosystem, how it functions and the wider implications for society. This model has particular resonance as many of the issues and impacts will be recognised as common to protected areas generally.

TAIB's Project S'Albufera has achieved an enormous amount at low cost. From the very start the project has relied heavily on the volunteer sector. For a project to survive over a long period of time, some administrative funding is required. In the case of TAIB, funding has met various expenses, including equipment and materials; and to pay an honorarium to an administrator working part-time. The administrator responsibility demands planning and organisational time outside the fieldwork and capacity building sessions, amounting in the current case to approximately three months per annum. This is an important point to take into account. Very few people would be able to commit to such a time scale and such sustained administration commitment without monetary justification. Without this incentive, similar projects are likely to falter.

Evaluation of the cost effectiveness of such a project should not overlook the hidden values the programme provides for society. Some of TAIB's findings are described in detail above in order to reveal those hidden values. The paper uses a number of examples to flag up social and economic impacts. These need to be known and taken into account by planners, including government, to avoid negative and costly future outcomes. The economic value of long-term monitoring as an early warning system far outweighs the modest costs. The financial cost to society of inaction could run into millions.

The issues raised here are particularly relevant to island situations, but have wider implications too - especially for the Mediterranean. It is generally accepted in conservation management that planning should be based on knowledge. 
Long-term studies at s'Albufera indicate that this should extend to land use and other economic planning as well. TAIB catchment socio-economic studies indicate that local people are essential to the planning process and their inclusion promotes a concept of shared responsibility and stewardship in caring for the natural environment.

Short-term studies are the norm and long-term studies a rarity in the environmental conservation world. This is partly because short-term studies are "affordable" because they are short - no more than three years and often less - and partly because the value of long-term studies is not yet appreciated. This paper challenges that perception. The information and knowledge which TAIB has accumulated over the years would not have materialised in a short time-span.

In 2013, TAIB had to survive without funding. The project had fallen victim of the European financial crisis, which is particularly severe in Spain. But is this a false economy? Indeed it is, not just for the project but also for long-term studies. The Albufera Initiative for Biodiversity is a 25-year old model which demonstrates the social, economic and environmental benefits of knowledge and the potential costs of management without it. A lot can be achieved for a little outlay: better to spend low now than expensive later.

\section{ACKNOWLEDGEMENTS}

We gratefully acknowledge the Balearic Conselleria de Medi Ambient and Directorate of the P.N. s'Albufera de Mallorca for their support and permission to operate in the Parc; the various funding agencies and other practical supporters of TAIB, especially Mrs Pat Bishop and family; the specialist advisors who have helped with identifications and other scientific input free of charge; and, above all, the numerous scientists and volunteers whose generous commitment has sustained the project over the last 25 years. We also thank the paper's referees for their contribution towards improving the initial draft. The catalyst for the entire venture was the far-sighted environmentalist Max Nicholson, 1904-2003.

\section{REFERENCES}

Abma, J. (2008) - The moth and the climate. The effects of climate change on Lepidoptera species in s'Albufera de Mallorca. 46p., Internship Report, Biology Masters, Entomology Group, Wageningen University, Wageningen, Netherlands.

Adger, W.N.; Eakin, H.; Winkels, A. (2009) - Nested and teleconnected vulnerabilities to environmental change. Frontiers in Ecology and the Environment, 7:150-157. DOI: $10.1890 / 070148$

AEN (2009) - Programa de seguiment de papallones diürnes a Mallorca (BMS-Mallorca). Associació per a l'Estudi de la Natura, Mallorca, Spain. http://www.aen.cat/projecte. php?id=13 .

ALTER-Net (s/d) - ALTER-Net: A Long-Term Biodiversity, Ecosystem and Awareness Research Network. Europe's biodiversity, ecosystem and ecosystem services research network. http://www.alter-net.info

Andrew (2011) - Too many people: Mallorca's population. In: Alcudia Pollensa. 2p. http://alcudiapollensa.wordpress. com/2011/01/07/too-many-people-mallorcas-population.
Associació TAIB (2012) - Web dels papaions de Mallorca. Associació Trebellam per s'Albufera iles Illes Balears. www.papaionsdemallorca.info

Bäckstrand, K. (2004) - Civic Science for Sustainability: Reframing the Role of Experts, Policy-Makers and Citizens in Environmental Governance. Global Environmental Politics, 3(4):24-40. DOI: 10.1162/152638003322757916

Bagnoli, B.; Lucchi, A. (2000) - Dannosità e misure di controllo integrate. In: Lucchi, A. (Ed.), La metcalfa negli ecosistemi italiani. pp.65-88, ARSIA Regione Toscana, Italy. ISBN: 978-8882950170.

Baldock, D. (2014) - A provisional list of the wasps and bees of Mallorca, Balearic Islands, Spain (Hymenoptera aculeata: Chrysidoidea, Scolioidea, Vespoidea, Apoidea). Entomofauna, 35:333-404.

Barceló, B.; Mayol, J. (coord.) (1980) - Estudio Ecologico de la Albufera de Mallorca. 406p., ICONA, Departamento de Geografia, Universidad de Palma de Mallorca, Spain.

Borggreve, C. (1987) - Biodiversity conservation in S'Albufera Natural Park, an analysis of main relevant functions, (potential) land-use conflicts and related policies. 38p., Graduate thesis, Centre for Environment and Climate Studies and Department of Terrestrial Ecology and Nature Conservation, Wageningen Agricultural University, Holland. Unpublished.

BTO (s/d) - Volunteer surveys. British Trust for Ornithology. In: http://www.bto.org/volunteer-surveys.

Candela, L.; von Igel, W.; Javier Elorza, F.; Aronica, G. (2009) - Impact assessment of combined climate and management scenarios on groundwater resources and associated wetland (Majorca, Spain). Journal of Hydrology, 376(3-4):510-527. DOI: 10.1016/j. jhydrol.2009.07.057

Carles-Tolrá, M. (coord.) (2002) - Catálogo de los Diptera de España, Portugal y Andorra (Insecta). 323p., Monografías de la Sociedad Entomológica Aragonesa, Vol. 8, Zaragoza, Spain. ISBN: 84-93280704.

Carton, O.T.; Tunney, H.; Daly, K.; Ryan, M.; Kurz, I.; Doody, D.; Bourke, D.; Kiely, G.; Morgan, G.; Moles, R.; Jordan, P.; Ryan, D.; Irvine, K.; Jennings, E.; Magette, W.L.; Bruen, M.; Mulqueen, J.; Rodgers, M.; Johnston, P.; Bartley, P. (2008) - Eutrophication from Agricultural Sources: Integrated Report. EPA STRIVE Programme 2007-2013, Environmental Protection Agency, Co. Wexford, Ireland. Available at http://epa.ie/pubs/reports/ research/water/ERTDI\%20Report\%2081_Web.pdf

Cathala, B.; Ducos, G.; Karatzos, S. (2002) - Integrated assessment of water use, water policies and water management in the Inca-Sa Pobla catchment area (Mallorca) and analysis of selected management strategies in agriculture. 42p., MSc Thesis, Environmental Systems Analysis Group, Wageningen University, Netherlands. Unpublished.

CBD (s/d) - Invasive Alien Species. Convention on Biological Diversity. http://www.cbd.int/invasive.

Costa, S.; Pardal, M.A.; Azeiteiro, U.M. (2013) - The use of an Estuarine System (Mondego estuary, Portugal) as Didactic Tool to incorporate Education for Sustainable Development into School Curricula. Journal of Integrated Coastal Zone Management, 13(2):243-251. DOI: 10.5894/rgci417 
Costanza, R.; d'Arge, R.; de Groot, R.; Farber, S.; Grasso, M.; Hannon, B.; Limburg, K.; Naeem, S.; O’Neill, R.; Paruelo, J.; Raskin, R.; Sutton, P.; van den Belt, M. (1997) - The value of the world's ecosystem services and natural capital. Nature (ISSN 0028-0836), 387(6630):253260. Available at http://www.esd.ornl.gov/benefits_ conference/nature_paper.pdf

Daniel, T.C.; Sharpley, A.N.; Lemunyon, J.L. (1998) - Agricultural Phosporus and Eutrophication: A Symposium Overview. Journal of Environmental Quality (ISSN 1537-2537), 27(2):251-257. DOI: 10.2134/ jeq1998.00472425002700020002x

de Groot, R. S. (1992) - Functions of Nature: evaluation of nature in environmental planning, management and decision making. 315p., Wolters-Noordhoff, Amsterdam. ISBN: 9001355943.

de Groot, R. S.; Wilson, M. A.; Boumans, R. M. (2002) - A typology for the classification, description and valuation of ecosystem functions, goods and services. Ecological Economics, 41(3):393-408. DOI: 10.1016/S09218009(02)00089-7

Desneux, N.; Wajnberg, E.; Wyckhuys, K.A.G.; Burgio, G; Arpaia, S.; Narváez-Vasquez, C. A.; González-Cabrera, J.; Catalán-Ruescas, D.; Tabone, E.; Frandon, J.; Pizzol, J.; Poncet, C.; Cabello, T.; Urbaneja, A. (2010) - Biological invasion of European tomato crops by Tuta absoluta: ecology, geographic expansion and prospects for biological control. Journal of Pest Science (ISSN 1612-4766), 83(3):197-215. DOI: 10.1007/s10340-010-0321-6

Duarte, C.M.; Chiscano, C.L. (1999) - Seagrass biomass and production: a reassessment. Aquatic botany, 65(14):159-174. DOI: 10.1016/S0304-3770(99)00038-8

Earthwatch Europe (1991) - Project S'Albufera. A new model for environmental research. 44p., Earthwatch Europe, Oxford, United Kingdom.

Ebejer, M.J. (2006) - Some Chloropidae (Diptera) from the Balearic Islands (Spain) with particular reference to Parc Natural de s'Albufera de Mallorca. Bolletí de la Societat d'Història Natural de les Illes Balears (ISSN 0212-260X), 49:173-184, Palma de Mallorca, Spain. Available at http://ibdigital.uib.cat/greenstone/ collect/bolletiHistoriaNaturalVolums/index/assoc/ Bolleti_/2006v049.dir/Bolleti_2006v049.pdf

Echevarría, L.; Gómez, A.; Piriz, C.; Quintas, C.; Tejera, R; Conde, D. (2013) - Capacity building for local coastal managers: a participatory approach for Integrated Coastal and Marine Zones Management in Uruguay. Journal of Integrated Coastal Zone Management, 13(4):1-18. DOI: $10.5894 /$ rgci402

Facca, C.; Bilaničovà, D.; Pojana, G.; Sfriso, A.; Marcomini, A. (2014) - Harmful Algae in Venice Lagoon and in Po River Delta (Northern Adriatic Sea, Italy). The Scientific World Journal, 2014: art. ID 806032. DOI: 10.1155/2014/806032

Feenstra, B. J. (1998) - Economic importance of the Parc Natural de s'Albufera. 47p., MSc Thesis, Wageningen Agricultural University, Holland. Unpublished.

Férriz, I. (2009) - Distribution of the populations of Thymelaea velutina and Juniperus oxycedrus subspecies macrocarpa in the dunes of Es Comú, PN de s'Albufera,
Mallorca. In: Nick Riddiford \& Macu Férriz (eds.), TAIB Project S'Albufera: A Mediterranean model for the study of biodiversity and environmental change. The Albufera International Biodiversity Project Annual Report 2008, pp. 138-149, Mallorca, Spain. Available at http:// www.taib.info/download/fieldwork-reports/TAIBReport-2008.pdf

Férriz, I. (2010) - La potencialitat de l'ús públic d'Es Comú d'Abaix, PN de s'Albufera. Una primera aproximació a la seva anàlisi. In: Nick Riddiford \& Macu Férriz (eds.), TAIB Project S'Albufera: A Mediterranean model for the study of biodiversity and environmental change. The Albufera International Biodiversity Project Annual Report 2009, pp. 112-186, Mallorca, Spain. Available at http://www.taib.info/download/fieldwork-reports/ TAIB-Report-2009.pdf

Férriz, I. (2012) - Diagnóstico socio-ecológico de la Plana de sa Pobla-Muro, Mallorca. Buscando el camino hacia la sustentabilidad. 96p., Master's thesis, Universidad Pablo de Olavide \& Universidad Internacional de Andalucía, Spain. Unpublished.

Férriz, I. (2013) - Inventari de la biota asociada a ses aigües de ses Veles d'es camí de son Fornari. In: Nick Riddiford (ed.), TAIB Project S'Albufera: A Mediterranean model for the study of biodiversity and environmental change. The Albufera International Biodiversity Project Annual Report 2012, pp. 25-50, Mallorca, Spain. Available at http://www.taib.info/download/fieldwork-reports/ TAIB-Report-2012.pdf

Férriz, I.; Herrero, C. (2012) - Les papallones nocturnes com a indicadors del canvi climàtic al Parc Natural de s'Albufera. Commissioned report to Govern de les Illes Balears \& Obra Social "La Caixa”. Associació TAIB, Parc Natural de s'Albufera de Mallorca. Unpublished.

Férriz, I.; Honey, M.R.; Riddiford, N.J. (2006) - Els Heteròcers del Parc Natural de ses Salines d'Eivissa i Formentera (Illes Balears). Bolletí de la Societat d'Història Natural de les Illes Balears (ISSN 0212-260X), 49:199-211, Palma de Mallorca, Spain. Available at http://ibdigital.uib.cat/ greenstone/collect/bolletiHistoriaNatural/index/assoc/ Bolleti_/2006v049/p199.dir/Bolleti_2006v049p199.pdf

Fibiger, M.; Agassiz, D. (2001) - Araeopteron ecphaea, a small noctuid moth in the West Palearctic (Noctuidae: Acontiinae). Nota Lepidopterologica (ISSN 0342-7536), 24(1/2):29-35, Societas Europaea Lepidopterologica, Innsbruck, Austria. Available at http://ia601600. us.archive.org/4/items/notalepidoptero242001 soci/ notalepidoptero242001soci.pdf

Fonda-Umani, S.; Ghirardelli, E.; Specchi, M. (1989) - Gli episodi di “mare sporco" nell'Adriatico dal 1729 ai giorni nostri. 178p., Regione Autonoma Friuli-Venizia Giulia, Direzione Regionale Dell'ambiente, Trieste, Italy.

Forcades, A.; Martorell, O. (2003) - Situación actual y perspectivas del turismo en las Illes Balears Bases para una contribución a la reflexión sobre su futuro. 42p., Cercle de Comerç \& Cambra d'Economia de Mallorca, Spain. Available at http://www.cambramallorca.com/ documentos/Desp_324.pdf

Foster, G.N.; Riddiford, N.J. (2011) - Cyphon lindbergi Nyholm (Col., Scirtidae) New for Europe. Entomologists' 
Monthly Magazine (ISSN: 0013-8908). 147:47-48, Pemberley Books, Iver, U.K..

Gabinet d'Anàlisi Ambiental i Territorial (2011) - Estudi de delimitació cartogràfica $i$

recuperació des ullals de s'Albufera de Mallorca. 149p., Conselleria d'Agricultura, Medi Ambient i Territori, Palma de Mallorca, Spain. Unpublished.

Galimont, A.; Candela, L.; Barón, A.; González, C. (2003) - Evolución de la intrusión salina en el llano de IncaSa Pobla, Mallorca. In: J. A. L. Geta, J. A. de la Orden, J. D. Gómez, G. Ramos, M. Mejías \& L. Rodriguez, Tecnología de la intrusión de agua de mar en acuiferos costeros: Países Mediterráneos I. IGME, Madrid, Spain. ISBN: 8478404708. Available at http://aguas.igme.es/ igme/publica/tiac-01/Area\%20V-12.pdf

Gelabert, B.; Servera, J.; Rodríguez-Perea, A. (2002) Características geomorfológicas del sistema dunar de la Bahía de Alcúdia (Isla de Mallorca). Geogaceta (ISSN 0213-683X). 32:215-218, Sociedad Geológica de España, Salamanca, Spain. http://www.sociedadgeologica.es/ archivos/geogacetas/Geo32/Art54.pdf

Green, R.; Riddiford, N.J. (2010) - A new species of bat (Pipistrellus pygmaeus) confirmed for Mallorca. Le Rhinolophe (ISSN: 1011-8098), 18:31-36, Muséum d'Histoire Naturelle de Genève, Genève, Switzerland.

Gowdy, J.M. (1997) - The Value of Biodiversity: Markets, Society, and Ecosystems. Land Economics (ISSN: 00237639), 73(1):25-41, University of Wisconsin, Madison, WI, U.S.A..

Hof, A.; Blázquez-Salom, M. (2013) - The Linkages between Real Estate Tourism and Urban Sprawl in Majorca (Balearic Islands, Spain). Land, 2(2):252-277. DOI: 10.3390/land2020252

Honey, M.R.; Férriz, I.; Riddiford, N.J. (2007) - Additional evidence supporting the migration of Cornifrons ulceratalis Lederer (Lep.: Crambidae, Evergestinae) in the Mediterranean region in October 2006. Entomologist's Record \& Journal of Variation (ISSN: 0013-8916), 119(5):237-238, Amateur Entomologists' Society, London, U.K.

Honey, M.R.; Orfila, M.; Riddiford, N.J. (2003) - Moths of s'Albufera des Grau and Illa d'en Colom (Menorca). Buttletí cientific dels Espais naturals protegits de les Illes Balears (ISSN: 1696-0009), Series 3, 1:19-21, Conselleria de Medi Ambient, Palma de Mallorca, Spain.

Honey, M.R.; Riddiford, N.J. (2003) - Moth fauna (Lepidoptera: Heterocera) of s'Albufera de Mallorca and other areas of the Balearic Islands - towards an up-dated check list of the Lepidoptera. Buttletí cientific dels Espais naturals protegits de les Illes Balears (ISSN: 1696-0009), Series 3, 1:35-39, Conselleria de Medi Ambient, Palma de Mallorca, Spain.

IBESTAT (2014) - Turistas con destino principal las Illes Balears por periodo, isla y pais de residencia. Institut d'Estadística de les Illes Balears (IBESTAT). In: https:// www.caib.es/ibestat/estadistiques/043d7774-cd6c4363-929a-703aaa0cb9e0/ef88f7cf-8e0b-44e0-b89785c2f85775ec/es/I208002_3001.px

INE (2014) - Series de población desde 1996. Cifras oficiales de la Revisión anual del Padrón municipal a 1 de enero de cada año. Detalle municipal: Illes Balears. Instituto Nacional de Estadística (INE), Madrid, Spain. In: http:// www.ine.es $/$ jaxiBD/tabla.do?per $=12 \&$ type $=\mathrm{db} \& \operatorname{divi}=\mathrm{D}$ POP\&idtab $=9$

ISC $(s / d)$ - Searching. Invasive Species Compendium. In: http://www.cabi.org/isc/

ISSG (s/d) - Biological invasions: a growing threat to biodiversity, buman health and food security. Invasive Species Specialist Group (ISSG), Species Survival Commission (SSC) of the International Union for Conservation of Nature (IUCN). In: http://www.issg.org/pdf/riopolicybrief.pdf

Koch, R.L. (2003) - The multicolored Asian lady beetle, Harmonia axyridis: A review of its biology, uses in biological control, and non-target imacts. Journal of Insect Science (ISSN 1536-2442) 3: 1-16, Entomological Society of America, Annapolis, MD, U.S.A.. Available at insectscience.org/3.32

Martínez, A.; Mayol, J. (eds.) (1995) - S'Albufera de Mallorca. 227p., Monografies de la Societat d'Historia Natural de les Illes Balears, Vol. 4. Editorial Moll, Palma de Mallorca, Spain. ISBN: 8427365063.

Martínez, A. (1988) - Caracteristiques limnologiques de s'Albufera de Mallorca. 708p., Doctoral Thesis, Departament de Biologia, Universitat de les Illes Balears, Palma de Mallorca, Spain. Unpublished.

McLennan, D.; Newbould, J. (2003) - Albufera de Mallorca Parc Natural: Guia de les Plantes; Plants of Paths, Marsh and Meadows. 176p., Pisces Publications, Oxford, UK. ISBN: 1874357242.

McRoy, C.P.; Helfferich, C. (1977) - Seagrass ecosystems: A Scientific Perspective. Marcel Dekker, New York, EEUU. ISBN: 0824764595.

MedWet (s/d) - MedWet Web Information System. www. wetlandwis.net

Mitsch, W.J.; Gosselink, J.G. (1993) - Wetlands. 722p., Van Nostrand Reinhold, New York. ISBN: 0442008058.

Moore, B.; Underdal, A; Lemke, P.; Loreau, M. (2001) Amsterdam Declaration on Earth System Science. 2p. In: Challenges of a Changing Earth: Global Change Open Science Conference, Amsterdam the Netherlands 10-13 July 2001. International Geosphere-Biosphere Programme (IGBP), International Human Dimensions Programme on Global Environmental Change (IHDP), World Climate Research Programme (WCRP) and International biodiversity programme (DIVERSITAS). http://www.igbp.net/about/ history/2001 amsterdamdeclarationonearthsystemscience. 4.1b8ae20512db692f2a680001312.html

Muñoz-Reinoso, J.C. (2004) - Diversity of maritime juniper woodlands. Forest Ecology and Management, 192(23):267-276. DOI: 10.1016/j.foreco.2004.01.039

Newbould, P.J.; Riddiford, N.J. (1990) - Monitoring for Global Change: The Earthwatch Europe S'Albufera Project. 80p., Earthwatch Europe, Oxford. Available at http:// www.taib.info/download/fieldwork-reports/TAIBReport-1989.pdf

NHM (s/d) - Volunteering. Natural History Museum, London, UK. In: http://www.nhm.ac.uk/about-us/ jobs-volunteering-internships/volunteering-internsinformation/index.html 
Owens, N. (2007) - Guide to the birds of s'Albufera Natural Park. 96p., TAIB and Parc Natural de s'Albufera, Mallorca, Spain. Available at http://www.taib.info/ download/guies/guide-to-the-birds-of-albufera-naturalpark-mallorca-2007-en.pdf

Owens, N.; Vicens, P. (2009) - Guia dels aucells del Parc Natural de s'Albufera de Mallorca. 96p., Conselleria de Medi Ambient, Illes Balears, Spain. Available at http:// www.mallorcaweb.net/gps/docs/guia_albufera_owens_ vicens_2009.pdf

Perring, F.H.; Walters, S.M. (1962) - Atlas of the British Flora. 432p., BSBI, London.

Picornell, C.; Ginard, A. (1995) - John Frederic Latrobe Bateman. In: Martínez A.; Mayol, J. (eds.), S'Albufera de Mallorca. pp.39-46, Monografies de la Societat d'Història Natural de les Balears, Editorial Moll, Palma de Mallorca, Spain. ISBN: 8427365063. Available at http://www. mallorcaweb.net/gps/docs/bateman.pdf

Pons, X.; Lumbierres, B.; Garcia, S; Manetti, P.L. (2002) - Metcalfa pruinosa (Say) (Homoptera: Flatidae), ¿una plaga potencial de plantas ornamentales en espacios verdes urbanos de Cataluña? Boletín de Sanidad Vegetal - Plagas (ISSN: 0213-6910) 28(2):217-222, Ministerio de Agricultura, Alimentación y Medio Ambiente, Madrid, Spain. Available at http://www.magrama.gob. es/ministerio/pags/biblioteca/revistas/pdf_plagas/BSVP_ 28-02-217-222.pdf

Portero-Marti, C. (2004) - Integrated Assessment of Grazing as a Management Tool in NP S'Albufera de Mallorca. 65p., MSC Thesis in Environmental Sciences, Environmental Systems Analysis Group, Wageningen University, Holland. Unpublished.

Rebassa, M.; Machado, J.; Martínez, J.L.; Torrens, S.; Oriola, M.C. (2009) - A Birding Tourist's Guide to Mallorca. Palma, Mallorca, Spain. ISBN: 978-846161061 7.

Rico, L. - Estudio piloto de los efectos de la erosión en las poblaciones de Juniperus oxycedrus sp. macrocarpa. Biodiversity and Conservation Department, Institut Mediterrani d'Estudis Avançats, Mallorca, Spain. Unpublished.

Riddiford, N.J. (ed.). (2002). Catàleg de Biodiversitat del Parc Natural de s'Albufera de Mallorca [Biodiversity Catalogue of the Albufera de Mallorca Natural Park]. 88p., Inventaris tècnics de Biodiversitat, 3. Direcció General de Biodiversitat, Conselleria de Medi Ambient, Govern Balear, Palma de Mallorca, Spain. Available at http://www.mallorcaweb.net/salbufera/docs/cataleg_ biodiversitat_2002.pdf

Riddiford, N.J. (2008) - The Albufera International Biodiversity Group (TAIB), un modelo de investigación aplicado a la conservación de especies. In: Mayol, J. y Viada, C. (eds.), Actas de El Rumbo del Arca. Congreso Técnico de Conservación de Fauna y Flora Silvestres, pp.181-189, Conselleria de Medi Ambient, Formentor, Mallorca, Spain. Available at http://www.caib.es/ sacmicrofront/archivopub.do?ctrl=MCRST272ZI76862 \&id $=76862$

Riddiford, N.J.; Fernández, L. (2009) - The fish of s'Albufera de Mallorca. In: Nick Riddiford \& Macu Férriz (eds.), TAIB Project S'Albufera: A Mediterranean model for the study of biodiversity and environmental change. The Albufera International Biodiversity Project Annual Report 2008, pp. 9-72, Mallorca, Spain. Available at http://www.taib.info/download/fieldwork-reports/ TAIB-Report-2008.pdf

Riddiford, N.J.; Férriz, I. (2009) - Submerged macrophytes and aquatic invertebrates of s'Albufera. In: Nick Riddiford \& Macu Férriz (eds.), TAIB Project S'Albufera: A Mediterranean model for the study of biodiversity and environmental change. The Albufera International Biodiversity Project Annual Report 2008, pp. 73-137, Mallorca, Spain. Available at http://www.taib.info/ download/fieldwork-reports/TAIB-Report-2008.pdf

Riddiford, N.J.; Mayol, J. (1996) - Case studies: s'Albufera de Mallorca. In: P. Tomàs-Vives, P. (ed.). 1996, Monitoring Mediterranean Wetlands: A Methodological Guide. pp.103118, MedWet Publication, Wetlands International, Slimbridge, UK and ICN, Lisbon, Portugal. Available at http://www.medwet.org/wp-content/pdf/monitoring2.pdf

Rodríguez-Perea, A; Servera, J.; Martín, J. A. (2000) Alternatives a la dependencia de les platges de les Balears de la regeneració artificial continuada: informe Metadona. 40 p. Universitat de les Illes Balears and Ajuntament de Calvià, Pedagogia Ambiental Collection, Palma de Mallorca, Spain. ISBN: 8476326300.

Rosenzweig, C.; Wilbanks, T.J. (2010) - The state of climate change vulnerability, impacts, and adaptation research: strengthening knowledge base and community. Climatic Change, 100(1):103-106. DOI: 10.1007/s10584-0109826-5

Royo, L.; Traveset, A.; Servera, J. (2007) - (An) Integrated Coastal Management of a beach-dune system, Western Mediterranean. Identifying and quantifying the sediment budget. International Conference on dune restoration and costal dune management, Santander, Cantabria, Spain. Unpublished.

Royo, L.; March, D.; Traveset, A. (2008) - Re-establishing the beach equilibrium for a public use and a sustainable conservation. In: Pons, G.X. (ed), V Jornades de Medi Ambient de les Illes Balears. Ponències $i$ resums, pp 386388, Societat d'Història Natural de les Balears, Palma de Mallorca, Spain. ISBN: 978-8496841574

Royo, L.; Noguera, M.; Reus, J. (2010) - Valoració i diagnosi socio-econòmica de s'Albufera de Mallorca. Una aproximació (multi-criteri) a partir dels seveis ecosistèmics. 274p., Associació TAIB and Conselleria de Medi Ambient, Mallorca, Spain. Unpublished.

RSPB (2014) - Volunteering. Royal Society for the Protection of Birds, Sandy, UK. In: https://www.rspb.org.uk/ volunteering/

Salamanca, O.R.; Rodríguez-Perea, A. (1999) - Los problemas de abastecimiento de agua en las Islas Baleares. In: A. Gil \& A. Morales, A., Los usos de agua en España, pp. 615-644, Caja de Ahorros del Mediterráneo, Instituto Universitario de Geografía de la Universidad de Alicante, Alicante, Spain. ISBN: 8475991866.

Salazar, R.D.; Riddiford, N.J.; Vicens, P. (2006) - A comparative dietary study of Cattle Egrets (Bubulcus ibis) and Little Egrets (Egretta garzetta) in S'Albufera Natural Park. Bolleti de la Societat d'Història Natural de 
les Illes Balears (ISSN: 0212-260X), 48:153-162, Palma de Mallorca, Spain. Available at http://ibdigital.uib.cat/ greenstone/collect/bolletiHistoriaNatural/index/assoc/ Bolleti_/2005v048/p153.dir/Bolleti_2005v048p153.pdf

Sargeant, L. (2002) - What factors determine niche partitioning in Ardeidae on an island wetland in the Mediterranean under conservation management? 37p., Thesis, MRes in Ecology and Environmental Management, University of York, UK. Unpublished.

Sato, M. (2002) - Notes on Dragonflies and Damselflies (Insecta: Odonata) in s'Albufera Natural Park, Mallorca: Status, Conservation Priorities and Bio-indicator Potential. 25p., Thesis, MRes in Ecology and Environmental Management, University of York, UK. Unpublished.

Sato, M.; Riddiford, N.J. (2008) - A preliminary study of the Odonata of s'Albufera Natural Park, Mallorca: status, conservation priorities and bio-indicator potential. Journal of Insect Conservation, 12:539-548. DOI: 10.1007/s10841-007-9094-5

Scheffer, M. (1998) - Ecology of Shallow Lakes. 357p., Chapman \& Hall, London, UK. ISBN: 0412749203.

SEO (s/d) - Voluntarios por las Aves y la Naturaleza. Sociedad Española de Ornitología, Madrid, Spain. http://www. seo.org/participa/voluntariado/

Servera, J. (2004) - Geomorfologia del Litoral de les Illes Balears. 88p., Edicions Documenta Balear, Palma de Mallorca, Spain. ISBN: 8496376109.

Servera, J.; Gelabert, B.; Rodríguez-Perea, A. (2009) Development and setting of the Alcudia Bay beach-dune system (Mallorca, Spain). Geomorphology, 110(3-4):172181. DOI: $10.1016 /$ j.geomorph.2009.04.008

Stuip, M. (2001) - An integrated assessment of interactions between tourism and nature conservation: a case study of Park Natural de s'Albufera de Mallorca. 63p., MSc Thesis, Wageningen University, Earthwatch Institute and Universitat de les Balears, Spain. Unpublished.

Suárez, M.G.; Pretus, J.L. (2008) - Informe sobre la caracterització de les variables fisicoquimiques i seguiment del cicle agroramader al Parc Natural de s'Albufera de Mallorca. 78p., Universitat de Barcelona Departament d'Ecologia, Fundació Bosch i Gimpera, Barcelona, Spain. Unpublished.

TAIB (2014) - TAIB website. The Albufera International Biodiversity group and Associació Treballam per s'Albufera i les Illes Balears, Mallorca, Spain. Available at http://www.taib.info/

Taylor, R. (1993) - Habitat and feeding ecology of Acrocephalus melanopogon and the impact of recent fires and management practices at S'Albufera de Mallorca. 55p., MSc in Conservation Dissertation, University College London, UK. Unpublished.

Tomàs-Vives, P. (ed.) (1996) - Monitoring Mediterranean Wetlands: A Methodological Guide. 150p., MedWet Publication: Wetlands International, Slimbridge, UK and ICN, Lisbon, Portugal. ISBN: 1900442043. Available at http://medwet.org/2010/02/monitoring-mediterraneanwetlands-a-methodological-guide/

Traveset, A.; Royo, L.; Servera, J. (2006) - Evolución geomorfológica y de vegetación del sistema dunar en la playa de Muro; Informe final, Proyecto especifico $I+D+i$
GIZC-VegeDuna. 53p., Govern Illes Balears and IMEDEA, Palma de Mallorca, Spain. Available at http:// www.costabalearsostenible.es/ATenpdf/1.1MA/2.Bio/ AnnaTraveset/Informefinal_VegeDuna_UGIZC_.pdf van der Perk, J. P. (1997) - Modelling the potential conflicts between Biodiversity Conservation and Water Quality Regulation in s'Albufera Natural Park, Mallorca. 40p., MSc Thesis, Centre for Environment and Climate Studies, Wageningen Agricultural University, Holland. Unpublished.

van der Straten, M.J.; Potting, R.P.J.; van der Linden, A. (2011) - Introduction of the tomato leafminer Tuta absoluta into Europe. Proceedings Netherlands Entomological Society Meetings (ISSN: 1388-8390), 22:23-30. Available at http://www.nev.nl/pages/ publicaties/proceedings/nummers/22/23-30.pdf

Veraart, J. (1999) - Selection of bio-indicators to monitor effects of agriculture and tourist developments on water quality and aquatic biodiversity in s'Albufera Natural Park, Mallorca. 122p., MSc Thesis, Wageningen University, Earthwatch Institute and Universitat de les Balears, Spain. Unpublished.

Veraart, J.; de Groot, R.S.; Perelló, G.; Riddiford, N.J.; Roijackers, R. (2004) - Selection of (bio) indicators to assess effects of freshwater use in wetlands: a case study of s'Albufera de Mallorca, Spain. Regional Environmental Change, 4(2-3):107-117. DOI: 10.1007/s10113-0040070-2

Veraart, J.; Van Nieuwaal, K.; Driessen, P.P.J.; Kabat, P. (2014) - From climate research to climate compatible development: experiences and progress in the Netherlands. Regional Environmental Change, 14(3):851863. DOI: $10.1007 / \mathrm{s} 10113-013-0567-7$

Vliet, A.H.; Bron, W.; Mulder, S.; Slikke, W.; Odé, B. (2013) - Observed climate-induced changes in plant phenology in the Netherlands. Regional Environmental Change (ISSN: 1436-378X), 14(3):997-1008. DOI: $10.1007 /$ s10113-013-0493-8

Whittingham, E. (1999) - The coastal zone of Alcudia Bay, Mallorca: an assessment of change and potential anthropogenic impacts on Posidonia oceanica seagrass habitat. 54p., MSc Dissertation, Centre for Tropical Coastal Management, University of Newcastle-uponTyne, UK. Unpublished.

WWF (2013) - WWF founder Max Nicholson dies. WWF Articles, World Wide Fund for Nature, Surrey, UK. In: http://www.wwf.org.uk/wwf_articles. cfm? unewsid $=1533$

Zingone, A. (2010) - Harmful Algal Blooms in the Mediterranean: an historical overview. In: CIESM (2010), Phytoplankton responses to Mediterranean environmental changes, no 40:19-24, CIESM Workshop Monograph, Tunis, 7-10 October 2009 (F. Briand Ed.), Monaco, France. Available at http://www.ciesm.org/ online/monographs/download.php?file=Tunis10.pdf 